\section{Pacific Northwest}

National Laboratory

Operated by Battelle for the

U.S. Department of Energy

\title{
Transportability Class of Americium in K Basin Sludge under Ambient and Hydrothermal Processing Conditions
}

C. H. Delegard

B. E. Schmitt

A. J. Schmidt

August 2006

Prepared for the U.S. Department of Energy

under Contract DE-AC05-76RL01830 


\title{
DISCLAIMER
}

This report was prepared as an account of work sponsored by an agency of the United States Government. Neither the United States Government nor any agency thereof, nor Battelle Memorial Institute, nor any of their employees, makes any warranty, express or implied, or assumes any legal liability or responsibility for the accuracy, completeness, or usefulness of any information, apparatus, product, or process disclosed, or represents that its use would not infringe privately owned rights. Reference herein to any specific commercial product, process, or service by trade name, trademark, manufacturer, or otherwise does not necessarily constitute or imply its endorsement, recommendation, or favoring by the United States Government or any agency thereof, or Battelle Memorial Institute. The views and opinions of authors expressed herein do not necessarily state or reflect those of the United States Government or any agency thereof.

\author{
PACIFIC NORTHWEST NATIONAL LABORATORY \\ operated by \\ BATTELLE \\ for the \\ UNITED STATES DEPARTMENT OF ENERGY \\ under Contract DE-AC05-76RL01830
}

Printed in the United States of America
Available to DOE and DOE contractors from the
Office of Scientific and Technical Information,
P.O. Box 62, Oak Ridge, TN 37831-0062;
ph: (865) 576-8401
fax: (865) $576-5728$
email: reports@adonis.osti.gov

\begin{abstract}
Available to the public from the National Technical Information Service,
U.S. Department of Commerce, 5285 Port Royal Rd., Springfield, VA 22161

ph: (800) 553-6847

fax: (703) 605-6900

email: orders@ntis.fedworld.gov

online ordering: http://www.ntis.gov/ordering.htm
\end{abstract}

This document was printed on recycled paper.

(9/2003) 


\title{
Transportability Class of Americium in K Basin Sludge under Ambient and Hydrothermal Processing Conditions
}

\author{
C. H. Delegard \\ B. E. Schmitt \\ A. J. Schmidt
}

August 2006

Prepared for the U.S. Department of Energy under Contract DE-AC05-76RL01830

Pacific Northwest National Laboratory

Richland, Washington 99352 


\section{Summary}

Sludge from the Hanford K fuel storage basins (K Basins) will be processed by hydrothermal means within the K Basin Sludge Treatment Project (STP) to convert residual uranium metal to uranium oxide. The behavior of americium-241 $\left({ }^{241} \mathrm{Am}\right)$ in sludge during the STP hydrothermal processing is assessed in the present report. This report establishes that ${ }^{241} \mathrm{Am}$ remains with the uranium under K Basin storage conditions and that ${ }^{241} \mathrm{Am}$ also remains with uranium for irradiated oxide fuel under conditions approaching those of the proposed STP process. The technical bases for using a "slow uptake" instead of a "moderate uptake" transportability class for ${ }^{241}$ Am for the K Basin STP dose consequence analysis also were established. Slow uptake classes are used for most uranium and plutonium oxides. A moderate uptake class has been used in prior STP analyses for ${ }^{241} \mathrm{Am}$ based on the properties of separated ${ }^{241} \mathrm{Am}$ and its associated oxide. However, when ${ }^{241} \mathrm{Am}$ exists as an ingrown progeny and as a small mass fraction within plutonium materials (i.e., is part of the plutonium matrix), it is appropriate to assign transportability factors of the predominant plutonium material (typically slow) to the ${ }^{241} \mathrm{Am}$. The transportability factor for ${ }^{241} \mathrm{Am}$ present in uranium phases in sludge likewise should be slow because it will not separate from the uranium phases during processing and because it exists as a small mass fraction as the ingrown progeny within the uranium oxide in sludge.

In this report, the Hanford Internal Dosimetry Technical Basis Manual ${ }^{(a)}$ guidance on transportability class assignment for ${ }^{241} \mathrm{Am}$, radiochemical characterization data on $\mathrm{K}$ Basin sludge, and uranium, plutonium, and americium behaviors in other irradiated fuel exposed to elevated temperatures and conditions similar to the STP are gathered. Key findings and conclusions from evaluation of the characterization data and published literature are summarized here.

- Plutonium and ${ }^{241} \mathrm{Am}$ make up very small fractions of the uranium within the $\mathrm{K}$ Basin sludge matrix. Plutonium is present at about 1 atom per 500 atoms of uranium and ${ }^{241} \mathrm{Am}$ at about 1 atom per 19000 atoms of uranium in the $\mathrm{N}$ Reactor fuel and its sludge residues.

- Plutonium and americium are found to remain with uranium in the solid phase in all of the $\sim 60$ samples taken and analyzed from various sources of $\mathrm{K}$ Basin sludge. The uranium-specific concentrations of plutonium and americium also remain approximately constant over a uranium concentration range (in the dry sludge solids) from 0.2 to $94 \mathrm{wt} \%$, a factor of $\sim 460$. This invariability demonstrates that ${ }^{241} \mathrm{Am}$ does not partition from the uranium or plutonium fraction for any characterized sludge matrix.

- Most of the K Basin sludge characterization data is derived spent nuclear fuel corroded within the $\mathrm{K}$ Basins at $10-15^{\circ} \mathrm{C}$. The STP process will react water-laden sludges from the $\mathrm{K}$ Basin in process vessels at $\sim 150-185^{\circ} \mathrm{C}$. Therefore, published studies with other irradiated fuel were examined. From these studies, the affinity of plutonium and americium for uranium in irradiated $\mathrm{UO}_{2}$ also was demonstrated at hydrothermal conditions $\left(150^{\circ} \mathrm{C}\right.$ anoxic liquid water) approaching those proposed for the STP process and even for hydrothermal conditions outside of the STP operating envelope (e.g., $150^{\circ} \mathrm{C}$ oxic and $100^{\circ} \mathrm{C}$ oxic and anoxic liquid water).

(a) PNNL-MA-860, Methods and Models of the Hanford Internal Dosimetry Program (2003). 
In summary, by demonstrating that the chemical and physical behavior of ${ }^{241} \mathrm{Am}$ in the sludge matrix is similar to that of the predominant species (uranium and for the plutonium from which it originates), a technical basis is provided for using the slow uptake transportability factor for ${ }^{241} \mathrm{Am}$ that is currently used for plutonium and uranium oxides. 


\section{Contents}

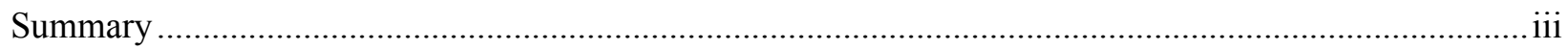

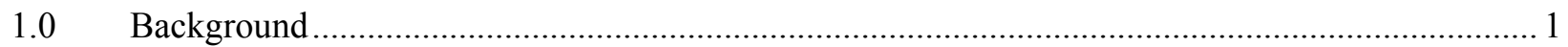

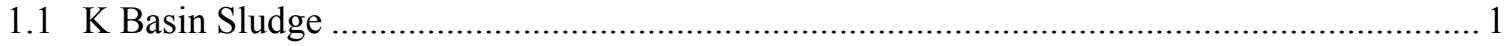

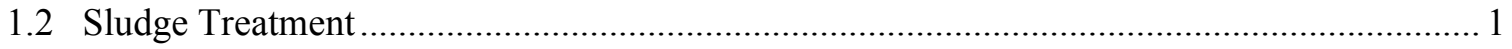

1.3 Transportability Classes - Uranium, Plutonium, and Americium ........................................ 2

2.0 Uranium Chemistry in the K Basins Sludge and in the STP Process ....................................... 3

3.0 Plutonium and Americium Disposition in Corroding Irradiated Uranium Metal Fuel

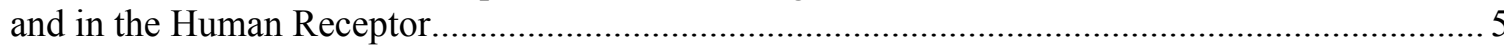

4.0 Uranium, Plutonium, and Americium Concentration Relationships in K Basin Sludge ................ 7

5.0 Plutonium and Americium Association with Uranium at Higher Temperatures ......................... 12

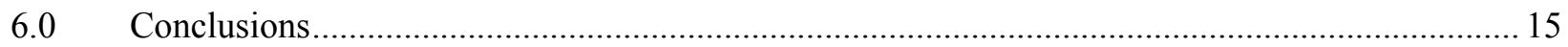

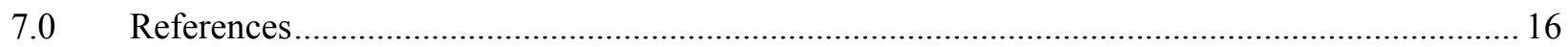

\section{Figures}

$1 \quad{ }^{239,240} \mathrm{Pu}$ Concentration with Respect to Uranium Concentration in Dry Sludge .......................... 10

$2 \quad{ }^{241}$ Am Concentration with Respect to Uranium Concentration in Dry Sludge ........................... 11

$3 \quad{ }^{241} \mathrm{Am}$ Concentration with Respect to ${ }^{239,240} \mathrm{Pu}$ Concentration in Dry Sludge ............................... 11

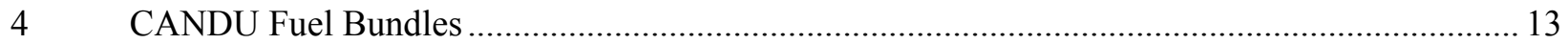

$5 \quad{ }^{238} \mathrm{U},{ }^{239,240} \mathrm{Pu}$, and ${ }^{241} \mathrm{Am}$ Leached from Irradiated CANDU Fuel under Various

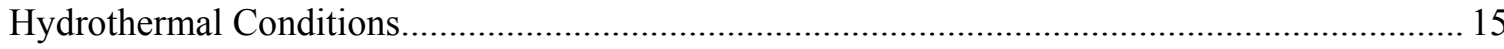




\section{Tables}

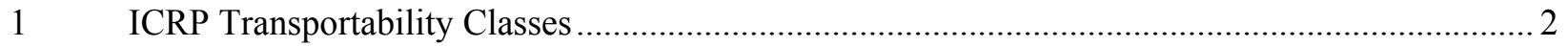

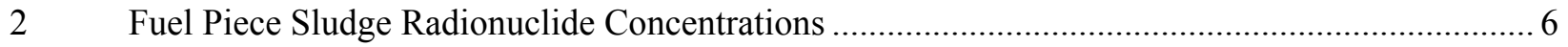

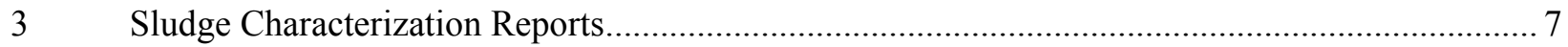

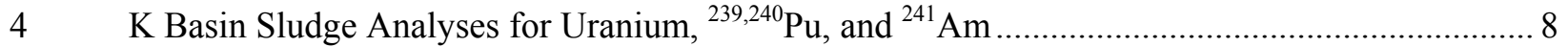

$5 \quad$ Fuel Qualities and Observations in Leach Testing ............................................................. 14 


\subsection{Background}

The behavior of americium-241 $\left({ }^{241} \mathrm{Am}\right)$ in $\mathrm{K}$ Basin sludge in processing for disposal is considered. Background information on the K Basin sludge, the proposed sludge treatment process, and the transportability classes for uranium, plutonium, and americium are described.

\subsection{K Basin Sludge}

Metallic uranium spent nuclear fuel (SNF) was stored in two water-filled concrete pools, 105-K East Basin (KE Basin) and 105-K West Basin (KW Basin), at the United States Department of Energy (U. S. DOE) Hanford Site in southeastern Washington State. These fuel storage pools contain hazardous substances that primarily result from the degradation of the SNF. The hazardous substances consist of the SNF, sludge, debris, and contaminated water. For the purposes of differentiating SNF and debris from sludge, any material that will pass through a screen with $0.635 \mathrm{~cm}(0.25 \mathrm{inch})$ openings is defined as sludge. Sludge currently or formerly on the floor and in the pits of the KE Basin is a mixture of fuel corrosion products (including metallic uranium, and fission and activation products), small fuel fragments, iron and aluminum oxide, concrete grit, sand, dirt, operational debris, and biological debris. The large quantity of fuel corrosion products in the KE Basin floor and pit sludge is a result of the open tops, and in many cases open-screened bottoms, of the fuel storage canisters. Because the SNF stored in the KW Basin was placed in closed containers with a corrosion inhibitor before storage, most of the corrosion products were retained within the canisters, and the historic sludge buildup in the KW Basin is of much smaller volume than that in KE Basin. Sludge that was contained in the KE and KW Basin fuel storage canisters consists primarily of fuel corrosion products. Sludge from the KE and KW basin floor and pits is being consolidated into engineered containers. The container systems consist of a series of large tanks, located under water in both $\mathrm{K}$ Basins, to isolate the sludge from the floor while maintaining it under the general Basin pool water. The box-shaped rectangular containers typically hold 8 to $25 \mathrm{~m}^{3}$ of this Container Sludge.

All KE and KW fuel was washed in the Primary Cleaning Machine (PCM) located in the West Bay of the KW Basin. Sludge generated from fuel washing was vacuumed into the Integrated Water Treatment System (IWTS). In the IWTS, pieces of material larger than 0.25 inch $(6350 \mu \mathrm{m})$ are removed in strainers. Of the material passing the strainers, the larger particles $(\sim 500$ to $600 \mu \mathrm{m}$ up to $6350 \mu \mathrm{m})$ are retained in knockout pots (KOPs) and is called KOP Sludge. After passing through the KOPs, the IWTS sludge stream enters the settler tanks (ten 20-inch diameter, 16-ft long tanks, operated in parallel) where the finer particulate sludge $(<500$ to $600 \mu \mathrm{m})$ collects by sedimentation. The collected material is called Settler Tank Sludge.

\subsection{Sludge Treatment}

The K Basins Closure Project (KBC) Project is responsible to DOE for operation of the fuel storage pools and the materials that they contain. The KBC Project mission includes containment, safe removal, treatment, and transportation of all sludge (treated or untreated) from these storage basins. As part of the KBC Project, sludge is to be retrieved and processed at Cold Vacuum Drying Facility (CVDF) under the Sludge Treatment Project (STP) process. The objective of the treatment is to eliminate uranium metal from the sludge by its further corrosion into chemically stable oxide forms that will be grouted and cast into drums. The process also is expected to corrode the contained plutonium metal that was formed in the 
uranium metal fuel during neutron exposure (burnup) in the reactor as well as the ingrown ${ }^{241}$ Am progeny of plutonium-241 $\left({ }^{241} \mathrm{Pu}\right)$. The ${ }^{241} \mathrm{Am}$, as will be seen, is a very small fraction of the mass of the mixture.

The uranium corrodes in water to form uranium dioxide, $\mathrm{UO}_{2}$. The $\mathrm{UO}_{2}$ has little affinity for the parent uranium metal and sloughs off to expose fresh metal to the water reactant. As a result, the uranium metal is not protected from further corrosion, the corrosion rate at a given temperature is proportional to the exposed metal surface area, and the metal particle diameter decreases linearly with time. This behavior has been observed not only for unirradiated uranium metal but also for pieces and particles of irradiated $\mathrm{N}$ Reactor fuel, the source material for the K Basin sludge (Schmidt et al. 2003).

\subsection{Transportability Classes - Uranium, Plutonium, and Americium}

Nuclear safety evaluations, including dose consequence evaluations, are being performed in support of the development of the authorization basis for the STP Project. For the dose consequence evaluations, three broad transportability (or solubility) classes have been defined for use with ICRP 68 and 72 (ICRP 1994, 1995a; ICRP is International Commission on Radiological Protection) inhalation dose conversion factors (DCFs). The three classes relate the absorption rate from the respiratory tract to body fluids, and are defined as fast $(\mathrm{F})$, moderate $(\mathrm{M})$, and slow $(\mathrm{S})$.

- Class F - Deposited materials that are readily absorbed into body fluids from the respiratory tract (Fast absorption).

- Class M - Deposited materials that have intermediate rates of absorption into body fluids from the respiratory tract (Moderate absorption).

- Class S - Deposited materials that are relatively insoluble in the respiratory tract (Slow absorption).

These classes are equivalent to the older ICRP publication 30 (ICRP 1979) classes D, W, and Y as shown in Table 1.

Table 1. ICRP Transportability Classes

\begin{tabular}{||c|c|}
\hline ICRP Publications 68 and 72 & ICRP Publication 30 \\
\hline F (fast) & D (day) \\
\hline M (moderate) & W (week) \\
\hline S (slow) & Y (year) \\
\hline
\end{tabular}

The transportability of uranium and plutonium varies greatly depending on the chemical form. In ICRP publication 68 (ICRP 1994) and publication 30 (ICRP 1979), highly insoluble uranium oxides $\mathrm{UO}_{2}$ and $\mathrm{U}_{3} \mathrm{O}_{8}$ (and presumably, $\mathrm{U}_{4} \mathrm{O}_{9}$ and $\mathrm{U}_{3} \mathrm{O}_{7}$ ) were identified as belonging to class $\mathrm{S}$ or $\mathrm{Y}$, respectively. Slightly soluble hexavalent uranium oxides $\left(\mathrm{UO}_{3}\right)$ were identified as belonging to class $\mathrm{M}$ or W. In ICRP publication 19 (ICRP 1972), plutonium oxides were identified as belonging to class Y. It was specifically noted that no plutonium compounds were assigned to class D. This approach was essentially endorsed by ICRP publication 68 (ICRP 1994), which assigned insoluble plutonium oxides to absorption type $\mathrm{S}$ and unspecified compounds to type M. ICRP publication 71 (ICRP 1995b) states that separated americium oxides appear to act as absorption type $\mathrm{M}$. 
The biokinetic behavior of uranium, plutonium, and americium from the ICRPs are summarized in the Hanford Internal Dosimetry Technical Basis Manual. ${ }^{\text {(a) }}$ This manual is used a reference document for internal dosimetry and is useful for nuclear dose safety consequence analysis. The ICRPs present material transportabilities for primary pure compounds. The Hanford Internal Dosimetry Technical Basis Manual extends the ICRP by considering situations in which the material of interest is dispersely distributed by radioactive decay in-growth in a predominant bulk host material. When combinations of transportability classes exist within a given matrix, the transportability of the mixed matrix is assumed to be that of the predominant material. For example, in a plutonium oxide matrix containing americium oxide as an ingrown trace material, the transportability of the americium oxide is assumed to be the same as that of the major mass constituent of the matrix (Eidson 1980). This was found to be consistent with other results (Stradling and Stather 1989). The corroded spent fuel for the STP is a uranium oxide matrix with the plutonium and americium oxides as generated and ingrown trace materials. Thus, the americium is expected to exhibit the class $\mathrm{S}$ behavior of the host matrix (uranium oxide), rather than the class $\mathrm{M}$ behavior normally expected of separated americium oxide. The above-described behavior would not be the case if the matrix was a simple blend of the two oxide powders or if americium were somehow transported out of the matrix.

The sludge material in the $\mathrm{K}$ Basins will contain a mix of metal and their corrosion products (e.g., uranium and plutonium metal and oxides). The ICRP biokinetics models do not explicitly address uranium metal although metal uptake is generally considered to be slow based on its low solubility. Studies by PNNL examined the variability in solubility classes from handling of uranium ingots and exposure to depleted uranium. The observed biokinetics for handling uranium ingots show a mixed class behavior ranging from $10 \%$ fast (class F) and $90 \%$ slow (class S) to $21 \%$ class F and $79 \%$ class S. Assays from exposures to depleted uranium (DU) identified a $20 \%$ class $\mathrm{F}$ and $80 \%$ class $\mathrm{S}$ uptake. ${ }^{(\mathrm{b})}$ However, ICRP 68 and 72 calculate that for uranium inhalation, the effective dose is higher for slow uptake than for fast. Thus, it is more conservative to assume $100 \%$ class $\mathrm{S}$ for uranium than to assume a mixed $\mathrm{S}$ and $\mathrm{F}$ class. This analysis also shows that the uptake class for uranium is class $\mathrm{S}$ for both pre- and postcorroded uranium (i.e., the completeness of the uranium metal oxidation has no effect). Based on these evaluations, the americium would be expected to exhibit the class $\mathrm{S}$ behavior of the host matrix (uranium), rather than the class $\mathrm{M}$ behavior normally expected of americium by itself.

The present paper study gives confidence that plutonium and americium will remain with the solid phase and specifically with uranium during the hydrothermal STP processing of K Basin sludge, and that the transportability class of the host uranium can be used for the americium.

\subsection{Uranium Chemistry in the $\mathrm{K}$ Basins Sludge and in the STP Process}

The uranium in $\mathrm{K}$ Basin sludge was introduced to the KE and KW fuel storage Basins as irradiated uranium metal fuel covered in Zircaloy- 2 cladding. If the cladding was breached, which was often the case, the $\sim 10-15^{\circ} \mathrm{C}$ water in the $\mathrm{K}$ Basins could reach the uranium metal and react to corrode the metal,

(a) PNNL-MA-860, Methods and Models of the Hanford Internal Dosimetry Program (2003).

(b) Letter Report to Monte J. Sula from Darrell R. Fisher, January 20, 1986, "Particle Size Distribution and Solubility of Uranium Aerosols in 333 and 303M Buildings at UNC, and PNL's 306W Building" (copy available in Hanford Radiological Records Historical File). 
forming uranium hydride, $\mathrm{UH}_{3}$, as an intermediate and then uranium dioxide, $\mathrm{UO}_{2}$. The product $\mathrm{UO}_{2}$ can be oxidized further if exposed to dissolved oxygen or peroxide present in the Basins.

Characterization studies were performed for sludge from the KE floor and canisters, sludge from the KW canisters, and sludge solids found as coatings on fuel and as deposits in fuel crevices. The characterization studies included identification of the phases by X-ray diffractometry, XRD (Makenas et al. 1996, 1997, 1998, 1999; Baker and Welsh; ${ }^{(a)}$ Shelor et al. 2004). Evidence for the presence of uranium metal in the sludge was not found by XRD but was found in settling tests in which $\mathrm{H}_{2}$, and krypton and xenon fission product gases, were observed to be generated from the sludge (Makenas et al. 1997) and in subsequent testing in which the same gases were released during heating of the sludge in closed vessels (e.g., Delegard et al. 2000). Uranium phases identified in the sludge by XRD include $\mathrm{UH}_{3}$, increasingly oxidized uranium oxide phases $\left(\mathrm{UO}_{2}, \mathrm{U}_{4} \mathrm{O}_{9}, \mathrm{U}_{3} \mathrm{O}_{7}, \mathrm{U}_{3} \mathrm{O}_{8}\right)$, schoepites $\left(\mathrm{UO}_{3} \cdot 2 \mathrm{H}_{2} \mathrm{O}, \mathrm{UO}_{2.86} \cdot 1.5 \mathrm{H}_{2} \mathrm{O}\right)$, other oxyhydroxides (uranium mineral phases such as $\mathrm{Na}_{2} \mathrm{U}_{2} \mathrm{O}_{7} \cdot 6 \mathrm{H}_{2} \mathrm{O}, \mathrm{K}_{2} \mathrm{UO}_{4}, \mathrm{CaU}_{6} \mathrm{O}_{19} \cdot 12 \mathrm{H}_{2} \mathrm{O}$ ), and uranyl peroxides $\left(\mathrm{UO}_{4} \cdot 2 \mathrm{H}_{2} \mathrm{O}\right.$ and $\left.\mathrm{UO}_{4} \cdot 4 \mathrm{H}_{2} \mathrm{O}\right) .{ }^{(\mathrm{b})}$

The solubility of crystalline $\mathrm{UO}_{2}$ in water at neutral $\mathrm{pH}(\sim 4-8)$ is about $10^{-9}$ moles per liter $(\underline{\mathrm{M}})$ and poorly crystalline hydrated $\mathrm{UO}_{2}$, perhaps compromised by trace hexavalent uranium, about $3 \times 10^{-5} \underline{\mathrm{M}}$. The solubility of schoepite is about $10^{-4} \underline{\mathrm{M}}$ at pH 5 and decreases to about $10^{-5} \underline{\mathrm{M}}$ at pH 7-9 where $\mathrm{Na}_{2} \mathrm{U}_{2} \mathrm{O}_{7}$ might start to appear (Puigdomènech and Bruno 1988). The other oxyhydroxides have lower solubility than the schoepites because they form from schoepite when the appropriate cation $(\mathrm{K}, \mathrm{Ca})$ is present in sufficient concentration (Sandino and Grambow 1994). For example, the solubility of becquerelite $\left(\mathrm{CaU}_{6} \mathrm{O}_{19} \cdot 12 \mathrm{H}_{2} \mathrm{O}\right)$ is about $10^{-4} \mathrm{M}$ at $\mathrm{pH} 5$ but decreases to about $10^{-7} \mathrm{M}$ at $\mathrm{pH}$ 7-9 (Rai et al. 2002). The solubilities of the studtite phases are $\sim 10^{-5} \mathrm{M}$ at pH 7 (Amme 2002). The chemical forms of uranium found in the $\mathrm{K}$ Basin sludge ( $\mathrm{pH} 4.5$ to 8.5$)$ thus are uranium metal, small amounts of hydride $\left(\mathrm{UH}_{3}\right)$, and poorly soluble oxides and oxyhydroxide mineral phases.

The transformation of uranium metal to these phases occurs in order of the uranium oxidation state from (0) in the metallic fuel, to (III) for $\mathrm{UH}_{3}$ and (IV) for $\mathrm{UO}_{2}$ from the primary fuel corrosion processes, and finally to (VI) for fully oxidized schoepite, the oxyhydroxide minerals, and uranyl peroxide. The reactions above the (IV) oxidation state occur by reaction with dissolved oxygen gas from the air or by reaction with oxygen or peroxide produced by radiolysis (see, for example, Ekeroth et al. 2006).

$$
\mathrm{UO}_{2}+\mathrm{O}\left(\text { from } \mathrm{O}_{2} \text { or } \mathrm{H}_{2} \mathrm{O}_{2}\right)+2 \mathrm{H}_{2} \mathrm{O} \rightarrow \mathrm{UO}_{3} \cdot 2 \mathrm{H}_{2} \mathrm{O}
$$

In the absence of dissolved oxygen or radiolytic effects (e.g., production of hydrogen peroxide, $\mathrm{H}_{2} \mathrm{O}_{2}$ ), the highest uranium oxidation state in sludge would be (IV) as in $\mathrm{UO}_{2}$. Based on the prevalence of $\mathrm{UO}_{2}$ (and the related oxides $\mathrm{U}_{4} \mathrm{O}_{9}, \mathrm{U}_{3} \mathrm{O}_{7}$, and $\mathrm{U}_{3} \mathrm{O}_{8}$ ) in the sludge, the reactions to oxidize $\mathrm{UO}_{2}$ to hexavalent compounds such as schoepite evidently are slower in the $\mathrm{K}$ Basins than is the reaction to form $\mathrm{UO}_{2}$ from uranium metal.

(a) Letter report, "Summary of Initial Laboratory Data from the Consolidated and Single Pull Core Sludge Sampling Campaigns," to K. L. Pearce, 01-SNF/RBB-004, Spent Nuclear Fuel Project, Fluor Hanford, Richland, WA (May 10, 2001).

(b) The sludge also contains water, Zircaloy-2 cladding fragments, iron and aluminum oxide/hydroxide corrosion products from Basin metal structures, concrete sloughed from the Basin walls, infiltrated soil minerals (e.g., clays, quartz), both organic and inorganic ion exchange media lost from water treatment systems, fabricated debris (metal hardware, plastic, graphite gasket material), flocculating agent, and biological materials (e.g., insects, plant stems). 
Corrosion of the uranium metal and the $\mathrm{UH}_{3}$ under the anoxic hydrothermal conditions $\left(150-185^{\circ} \mathrm{C}\right.$ pressurized liquid water) of the proposed STP process will produce $\mathrm{UO}_{2}$ and $\mathrm{H}_{2}$ :

$$
\begin{gathered}
\mathrm{U}+2 \mathrm{H}_{2} \mathrm{O} \rightarrow \mathrm{UO}_{2}+2 \mathrm{H}_{2} \\
2 \mathrm{UH}_{3}+4 \mathrm{H}_{2} \mathrm{O} \rightarrow 2 \mathrm{UO}_{2}+7 \mathrm{H}_{2}
\end{gathered}
$$

The evolved $\mathrm{H}_{2}$ will ensure chemically reducing conditions in the STP process and the oxidation of uranium metal and $\mathrm{UH}_{3}$ will cease at $\mathrm{UO}_{2}$. The product $\mathrm{H}_{2}$ may also chemically reduce the more oxidized uranium sludge compounds within the reaction pressure vessel and cause, for example, some schoepite to convert to $\mathrm{UO}_{2}$ as has been observed under milder hydrothermal conditions (Ekeroth et al. 2004):

$$
\mathrm{UO}_{3} \cdot 2 \mathrm{H}_{2} \mathrm{O}+\mathrm{H}_{2} \rightarrow \mathrm{UO}_{2}+3 \mathrm{H}_{2} \mathrm{O}
$$

Therefore, for streams with high metal and total uranium concentrations, such as KOP and Container Sludge, chemical reduction of $\mathrm{U}(\mathrm{VI})$ oxides and minerals to $\mathrm{UO}_{2}$ might be expected. Alternatively, the quantities of uranium metal in each hydrothermal process batch (and thus the quantity of $\mathrm{H}_{2}$ ) may approach zero for certain batches meaning little if any chemical reduction caused by uranium metal will occur. For Container Sludges having little or no metal, trace residual dissolved oxygen and radiolytic peroxide then may convert a small amount of the $\mathrm{UO}_{2}$ to $\mathrm{U}(\mathrm{VI})$ compounds. Overall, the quantities of chemical reductant (hydrogen gas from uranium metal corrosion) potentially present in the process batches will overshadow the chemical oxidants from dissolved oxygen and radiolytic peroxide with the effect that it is more likely that $\mathrm{U}(\mathrm{VI})$ minerals will be reduced to $\mathrm{UO}_{2}$ or other uraninites (e.g., $\mathrm{U}_{4} \mathrm{O}_{9}$ ) than for $\mathrm{UO}_{2}$ to be oxidized to $\mathrm{U}(\mathrm{VI})$ minerals. The uranium compounds present in the post-treatment sludge thus will range from the $\mathrm{UO}_{2}$ newly generated from uranium metal and hydride corrosion to the higher oxides and oxyhydroxide minerals. The STP process will eliminate $\mathrm{UH}_{3}$ and uranium metal.

Data on the uranium oxide phases identified in the K Basin sludge samples was used along with knowledge of uranium chemistry and other sludge properties to estimate the as-found or starting state uranium compound phase distribution for various sludge streams (Plys and Schmidt 2006; Schmidt and Delegard 2003). The uranium phase composition in the combined KE floor/pit and KE canister sludges was estimated to be equal uranium mole fractions of $\mathrm{UO}_{2}, \mathrm{U}_{4} \mathrm{O}_{9}$, and $\mathrm{UO}_{3} \cdot 2 \mathrm{H}_{2} \mathrm{O}$. This combination contains materials of transportability class $\mathrm{S}$ or $\mathrm{Y}\left(\mathrm{UO}_{2}\right.$ and $\left.\mathrm{U}_{4} \mathrm{O}_{9}\right)$ and materials of class $\mathrm{M}$ or W $\left(\mathrm{UO}_{3} \cdot 2 \mathrm{H}_{2} \mathrm{O}\right)$. The uranium-bearing sludge phases generated from the KW Basin fuel, which were stored in closed canisters with a corrosion inhibitor, are less oxidized than the phases from the fuel stored in the open top canisters used in the KE Basin. The uranium phase composition for $\mathrm{KW}$ canister sludge, the representative source of Settler Tank Sludge, was estimated to be equal uranium mole fractions of $\mathrm{UO}_{2}$ and $\mathrm{U}_{4} \mathrm{O}_{9}$ and be transportability class $\mathrm{S}$ or $\mathrm{Y}$.

\subsection{Plutonium and Americium Disposition in Corroding Irradiated Uranium Metal Fuel and in the Human Receptor}

Plutonium was produced during the irradiation of uranium metal in the $\mathrm{N}$ Reactor to give isotopes of mass 238, 239, 240, 241, and 242 (or ${ }^{238} \mathrm{Pu},{ }^{239} \mathrm{Pu},{ }^{240} \mathrm{Pu},{ }^{241} \mathrm{Pu}$, and ${ }^{242} \mathrm{Pu}$ ). Table 2, derived from values for the nominal concentrations in fuel piece sludge (representative of KOP Sludge), shows that ${ }^{239} \mathrm{Pu}$ and ${ }^{240} \mathrm{Pu}$ 
are the most prevalent plutonium isotopes and constitute about $98 \mathrm{wt} \%$ of the total plutonium. Americium-241 arises from decay of the less prevalent 14.4-year half-life isotope ${ }^{241} \mathrm{Pu} .{ }^{(a)}$

Table 2. Fuel Piece Sludge Radionuclide Concentrations

\begin{tabular}{|c|c|}
\hline Isotope & $\begin{array}{l}\text { Pu Isotope, } \\
\text { Weight \% }\end{array}$ \\
\hline${ }^{238} \mathrm{Pu}$ & 0.16 \\
\hline${ }^{239} \mathrm{Pu}$ & 85.12 \\
\hline${ }^{240} \mathrm{Pu}$ & 12.74 \\
\hline${ }^{241} \mathrm{Pu}$ & 1.66 \\
\hline${ }^{242} \mathrm{Pu}$ & 0.32 \\
\hline${ }^{241} \mathrm{Am}$ & $2.58^{(b)}$ \\
\hline Element & g Element/g U \\
\hline $\mathrm{Pu}$ & $2.02 \mathrm{E}-03$ \\
\hline $\mathrm{Am}$ & $5.21 \mathrm{E}-05$ \\
\hline Isotope & $\mu \mathrm{Ci}$ Isotope/g U \\
\hline${ }^{239,240} \mathrm{Pu}$ & $1.65 \mathrm{E}+02$ \\
\hline${ }^{241} \mathrm{Am}$ & $1.79 \mathrm{E}+02$ \\
\hline \multicolumn{2}{|c|}{$\begin{array}{l}\text { (a) Derived from data taken from } \\
\text { Table 4-15 (Schmidt 2006). } \\
\text { (b) With respect to total plutonium } \\
\text { for decay to May } 31,1998 . \\
\end{array}$} \\
\hline
\end{tabular}

As seen in Table 2, plutonium comprises about $0.20 \mathrm{wt} \%$ of the uranium in the fuel piece sludge and ${ }^{241} \mathrm{Am}$ is about $2.6 \mathrm{wt} \%$ of the plutonium or $0.0052 \mathrm{wt} \%$ of the uranium. Americium ultimately will comprise about $4.3 \mathrm{wt} \%$ of the plutonium upon decay of the ${ }^{241} \mathrm{Pu}$. Because of the statistical nature of neutron irradiation, the plutonium as metal is created within the uranium metal fuel on an atom-by-atom basis. The ${ }^{241} \mathrm{Am}$ forming, in turn, from the decay of atomically dispersed ${ }^{241} \mathrm{Pu}$ likewise is present as atom-dispersed metal within the bulk irradiated uranium metal fuel. Plutonium thus is present at about 1 atom per 500 atoms of uranium and ${ }^{241} \mathrm{Am}$ at about 1 atom per 19000 of uranium.

The uranium metal initially corrodes to form $\mathrm{UO}_{2}$. Uranium, plutonium, and americium form isomorphous dioxides, each having the cubic fluorite structure with lattice parameter decreasing only slightly, in the order U-Pu-Am, from 0.5471 to 0.5396 to $0.5374 \mathrm{~nm}$ (Katz et al. 1986). Therefore, it is virtually certain that as the uranium metal fuel corrodes to form $\mathrm{UO}_{2}$, the plutonium and americium also will corrode to form their respective dioxides, $\mathrm{PuO}_{2}$ and $\mathrm{AmO}_{2}$, which, because of their very similar sizes, will easily remain within the structurally isomorphous $\mathrm{UO}_{2}$ host matrix.

(a) The decay date for the isotope values is May 31, 1998. Because ${ }^{241} \mathrm{Pu}$ decays to ${ }^{241}$ Am with a 14.4-year half-life (meaning 0.04814 of the ${ }^{241} \mathrm{Pu}$ decays per year), a cooling time of 19.5 years (i.e., discharge about 1978-1979), can be estimated for the fuel piece sludge based on the following equation and the relative ${ }^{241} \mathrm{Pu}$ and ${ }^{241} \mathrm{Am}$ concentrations:

$$
\text { Cooling time, years }=\frac{-\ln _{\mathrm{e}} \frac{{ }^{241} \mathrm{Pu}}{\left({ }^{241} \mathrm{Pu}+{ }^{241} \mathrm{Am}\right)}}{0.04814 / \text { year }}=\frac{-\ln _{\mathrm{e}} \frac{1.66}{(1.66+2.58)}}{0.04814 / \text { year }}=19.5 \text { years }
$$

N Reactor was last operated in 1986. The effective cooling time in fact is an average of the cooling times of the fuel elements whose corrosion products contributed to the sludge. 
It is seen that plutonium and particularly americium are trace constituents in the uranium matrix and that both are readily incorporated into $\mathrm{UO}_{2}$, the primary uranium metal corrosion product. Separation of the americium or plutonium from their strong association in the parent uranium matrix would require dissolution of the uranium matrix with the associated plutonium and americium. Uranium dioxide and other uranium phases found in the sludge are only soluble in water under acid conditions ( $\mathrm{pH}$ below $~ 1)$ or under conditions that are both oxidizing (e.g., aerated) and containing high carbonate concentrations.

These dissolution conditions are far from those occurring in the STP process. Therefore, at the temperature and $\mathrm{pH}$ ranges expected for the STP process, there is no mechanism to preferentially corrode, or separate, americium from the plutonium or either of them from the uranium. Being negligibly soluble, the $\mathrm{PuO}_{2}$ and $\mathrm{AmO}_{2}$ will tend to remain with the poorly soluble uranium phases, even as subsequent $\mathrm{UO}_{2}$ oxidation to the slightly more soluble U(VI) compounds occurs. On these bases, the plutonium and americium are expected to stay with the solid phase uranium and their concentrations relative to uranium remain unchanged from that of the starting fuel. In particular, the americium is expected to be distributed within the corroded fuel matrix and exhibit the same solubility characteristics as the bulk uranium and plutonium and not show the solubility of pure americium phases in both the as-settled sludge and in the STP process post-corroded sludge.

These conditions also are far from those occurring in a human receptor by inhalation. The lung $\mathrm{pH}$ is about 7-7.5. Therefore, americium will not partition from any uranium particles inhaled into the lungs. However, approximately $50 \%$ of particles deposited in the lungs are cleared by cilia and report into the gastrointestinal tract. If the low $\mathrm{pH}$ of the stomach contents dissolve the uranium compound particles, the americium likewise dissolves and has the opportunity to separate from the uranium. The uranium that is absorbed through the walls of the gut is small, $5 \%$, according to ICRP30 and even smaller, $0.05 \%$, for americium (ICRP 1979). Therefore, the separation of americium from uranium in the gastrointestinal tract is not of radiological significance.

\subsection{Uranium, Plutonium, and Americium Concentration Relationships in K Basin Sludge}

Extensive characterizations of $\mathrm{K}$ Basin sludge composition have been performed over the past 10 years (Table 3). The widely varying concentrations of uranium, ${ }^{239,240} \mathrm{Pu}$, and ${ }^{241} \mathrm{Am}$ in these diverse sludges may be compared to discern if, as expected, the plutonium and americium remain with uranium during corrosion and subsequent further oxidation reactions under Basin conditions.

Table 3. Sludge Characterization Reports

\begin{tabular}{||l|l||}
\hline \multicolumn{1}{|c|}{ Sludge Origin } & \multicolumn{1}{c|}{ Reference } \\
\hline KE Floor and Weasel Pit & Makenas et al. (1996) \\
\hline KE Canister & Makenas et al. (1997) \\
\hline KW Canister & Makenas et al. (1998) \\
\hline Internal Sludge and Coatings on Fuel & Makenas et al. (1999) \\
\hline KE Floor and Canister (consolidated and single-pull) & Baker and Welsh (2001) \\
\hline KE North Load Out Pit sludge & Shelor et al. (2004) \\
\hline $\begin{array}{l}\text { (a) Letter report, "Summary of Initial Laboratory Data from the Consolidated and Single Pull Core } \\
\text { Sludge Sampling Campaigns," to K. L. Pearce, 01-SNF/RBB-004, Spent Nuclear Fuel Project, } \\
\text { Fluor Hanford, Richland, WA (May 10, 2001). }\end{array}$ \\
\hline
\end{tabular}


The concentrations of uranium, ${ }^{239,240} \mathrm{Pu}$, and ${ }^{241} \mathrm{Am}$ in the sludge, of ${ }^{239,240} \mathrm{Pu}$ and ${ }^{241} \mathrm{Am}$ with respect uranium, and the ${ }^{239,240} \mathrm{Pu} /{ }^{241} \mathrm{Am}$ ratios derived from the reports listed in Table 3 are shown in Table 4. Uranium concentrations range from 2000 to $940,000 \mu \mathrm{g} \mathrm{U} / \mathrm{g}$ sludge or 0.2 to 94 weight $\%$ and vary by a factor of about 460 . Because the uranium concentration in $\mathrm{UO}_{2}$ is about $88 \mathrm{wt} \%$, concentrations above this value indicate that a significant fraction of $\mathrm{UH}_{3}$ or, more likely, uranium metal, exists in some of the sludge materials. The plutonium and americium concentrations also are seen to vary broadly in these sludge samples. The uranium-specific concentrations are relatively constant for the 61 samples having both uranium and plutonium values $\left(255 \pm 96 \mu \mathrm{Ci}^{239 / 240} \mathrm{Pu} / \mathrm{g} \mathrm{U}\right)$ and the 59 samples having both uranium and americium values $\left(235 \pm 111 \mu \mathrm{Ci}^{241} \mathrm{Am} / \mathrm{g} \mathrm{U}\right)$. These values are $30-50 \%$ higher than the $165 \mu \mathrm{Ci}$ ${ }^{239 / 240} \mathrm{Pu} / \mathrm{g} \mathrm{U}$ and $179 \mu \mathrm{Ci}^{241} \mathrm{Am} / \mathrm{g} \mathrm{U}$ values modeled for fuel pieces (Table 2). The higher plutonium and americium concentrations measured in the sludge likely reflects the greater exposure experienced by the sludge's source fuel material, which was at the ends and peripheries of the corroding fuel elements.

Table 4. K Basin Sludge Analyses for Uranium, ${ }^{239,240} \mathrm{Pu}$, and ${ }^{241} \mathrm{Am}$

\begin{tabular}{|c|c|c|c|c|c|c|}
\hline \multirow[b]{2}{*}{ Sample ID } & \multicolumn{6}{|c|}{ Concentration, dry sludge basis } \\
\hline & $\begin{array}{c}\mathrm{U}, \\
\mu \mathrm{g} / \mathrm{g}\end{array}$ & $\begin{array}{c}{ }^{239 / 240} \mathrm{Pu}, \\
\mu \mathrm{Ci} / \mathrm{g}\end{array}$ & $\begin{array}{l}{ }^{241} \mathrm{Am}, \\
\mu \mathrm{Ci} / \mathrm{g}\end{array}$ & $\begin{array}{r}{ }^{239 / 240} \mathrm{Pu}, \\
\mu \mathrm{Ci} / \mathrm{g} \mathrm{U}\end{array}$ & $\begin{array}{c}{ }^{241} \mathrm{Am}, \\
\mu \mathrm{Ci} / \mathrm{g} \mathrm{U}\end{array}$ & $\begin{array}{l}\mathrm{Am} / \mathrm{Pu}, \\
\mathbf{\mu C i} / \mathbf{\mu C i}\end{array}$ \\
\hline \multicolumn{7}{|c|}{ KE Floor \& Pit, Makenas et al. 1996} \\
\hline 1 & $4.37 \mathrm{E}+05$ & $3.00 \mathrm{E}+01$ & $7.44 \mathrm{E}+01$ & $6.86 \mathrm{E}+01$ & $1.70 \mathrm{E}+02$ & $2.48 \mathrm{E}+00$ \\
\hline 2 & $6.06 \mathrm{E}+04$ & $1.51 \mathrm{E}+01$ & $1.41 \mathrm{E}+01$ & $2.49 \mathrm{E}+02$ & $2.33 \mathrm{E}+02$ & $9.34 \mathrm{E}-01$ \\
\hline 3 & $1.44 \mathrm{E}+05$ & $6.07 \mathrm{E}+01$ & $5.28 \mathrm{E}+01$ & $4.22 \mathrm{E}+02$ & $3.67 \mathrm{E}+02$ & $8.70 \mathrm{E}-01$ \\
\hline 4 & $1.28 \mathrm{E}+05$ & $5.18 \mathrm{E}+01$ & $4.87 \mathrm{E}+01$ & $4.05 \mathrm{E}+02$ & $3.80 \mathrm{E}+02$ & $9.40 \mathrm{E}-01$ \\
\hline 5 & $1.18 \mathrm{E}+05$ & $3.13 \mathrm{E}+01$ & $2.99 \mathrm{E}+01$ & $2.65 \mathrm{E}+02$ & $2.53 \mathrm{E}+02$ & $9.55 \mathrm{E}-01$ \\
\hline 6 & $6.39 \mathrm{E}+04$ & $1.47 \mathrm{E}+01$ & $1.20 \mathrm{E}+01$ & $2.30 \mathrm{E}+02$ & $1.88 \mathrm{E}+02$ & $8.16 \mathrm{E}-01$ \\
\hline 8 & $2.49 \mathrm{E}+03$ & 4.03E-01 & $3.97 \mathrm{E}-01$ & $1.62 \mathrm{E}+02$ & $1.59 \mathrm{E}+02$ & $9.85 \mathrm{E}-01$ \\
\hline 9 & $3.21 \mathrm{E}+05$ & $3.36 \mathrm{E}+01$ & $4.02 \mathrm{E}+01$ & $1.05 \mathrm{E}+02$ & $1.25 \mathrm{E}+02$ & $1.20 \mathrm{E}+00$ \\
\hline 10 & $2.30 \mathrm{E}+04$ & $4.10 \mathrm{E}+00$ & $3.66 \mathrm{E}+00$ & $1.78 \mathrm{E}+02$ & $1.59 \mathrm{E}+02$ & 8.93E-01 \\
\hline 11 & $1.02 \mathrm{E}+05$ & $3.64 \mathrm{E}+01$ & $3.24 \mathrm{E}+01$ & $3.57 \mathrm{E}+02$ & $3.18 \mathrm{E}+02$ & $8.90 \mathrm{E}-01$ \\
\hline 12 & $3.28 \mathrm{E}+04$ & $4.58 \mathrm{E}+00$ & $3.73 \mathrm{E}+00$ & $1.40 \mathrm{E}+02$ & $1.14 \mathrm{E}+02$ & $8.14 \mathrm{E}-01$ \\
\hline 15 & $3.27 \mathrm{E}+04$ & $4.25 \mathrm{E}+00$ & $3.72 \mathrm{E}+00$ & $1.30 \mathrm{E}+02$ & $1.14 \mathrm{E}+02$ & $8.75 \mathrm{E}-01$ \\
\hline 16 & $1.12 \mathrm{E}+05$ & $1.91 \mathrm{E}+01$ & $1.47 \mathrm{E}+01$ & $1.71 \mathrm{E}+02$ & $1.31 \mathrm{E}+02$ & $7.70 \mathrm{E}-01$ \\
\hline 17 & $7.33 \mathrm{E}+04$ & $1.25 \mathrm{E}+01$ & $1.09 \mathrm{E}+01$ & $1.71 \mathrm{E}+02$ & $1.49 \mathrm{E}+02$ & $8.72 \mathrm{E}-01$ \\
\hline 18 & $1.99 \mathrm{E}+04$ & $3.26 \mathrm{E}+00$ & $2.52 \mathrm{E}+00$ & $1.64 \mathrm{E}+02$ & $1.27 \mathrm{E}+02$ & $7.73 \mathrm{E}-01$ \\
\hline 19 & $5.36 \mathrm{E}+04$ & $8.30 \mathrm{E}+00$ & $6.23 \mathrm{E}+00$ & 1.55 & $1.16 \mathrm{E}+02$ & $7.51 \mathrm{E}-01$ \\
\hline 20 & & $6.73 \mathrm{E}+01$ & $5.01 \mathrm{E}+01$ & & & $7.44 \mathrm{E}-01$ \\
\hline 21 & & $3.38 \mathrm{E}+01$ & $3.14 \mathrm{E}+01$ & & & $9.29 \mathrm{E}-01$ \\
\hline 23 & $5.84 \mathrm{E}+04$ & $7.98 \mathrm{E}+00$ & $8+00$ & +02 & $1.17 \mathrm{E}+02$ & $8.57 \mathrm{E}-01$ \\
\hline \multicolumn{7}{|c|}{ KE Canister, Makenas et al. 1997} \\
\hline $96-05$ & $5.85 \mathrm{E}+05$ & $1.53 \mathrm{E}+02$ & $1.33 \mathrm{E}+02$ & $2.62 \mathrm{E}+02$ & $2.27 \mathrm{E}+02$ & 8.69E-01 \\
\hline $96-08$ & $3.10 \mathrm{E}+05$ & $9.35 \mathrm{E}+01$ & & $3.02 \mathrm{E}+02$ & & \\
\hline $96-09$ & $1.31 \mathrm{E}+05$ & $3.40 \mathrm{E}+01$ & $3.26 \mathrm{E}+01$ & $2.60 \mathrm{E}+02$ & $2.49 \mathrm{E}+02$ & $9.59 \mathrm{E}-01$ \\
\hline $96-13$ & $7.40 \mathrm{E}+05$ & $1.10 \mathrm{E}+02$ & $7.20 \mathrm{E}+01$ & $1.49 \mathrm{E}+02$ & $9.73 \mathrm{E}+01$ & $6.55 \mathrm{E}-01$ \\
\hline $96-15$ & $4.92 \mathrm{E}+05$ & $9.54 \mathrm{E}+01$ & $7.04 \mathrm{E}+01$ & $1.94 \mathrm{E}+02$ & $1.43 \mathrm{E}+02$ & $7.38 \mathrm{E}-01$ \\
\hline $96-04 \mathrm{U}$ & $2.97 \mathrm{E}+05$ & $1.90 \mathrm{E}+02$ & $1.87 \mathrm{E}+02$ & $6.40 \mathrm{E}+02$ & & $9.84 \mathrm{E}-01$ \\
\hline 96-04 L & $2.73 \mathrm{E}+05$ & $9.97 \mathrm{E}+01$ & $1.21 \mathrm{E}+02$ & $3.65 \mathrm{E}+02$ & $4.43 \mathrm{E}+02$ & $1.21 \mathrm{E}+00$ \\
\hline $96-06 \mathrm{M}$ & $6.11 \mathrm{E}+05$ & $1.04 \mathrm{E}+02$ & $9.95 \mathrm{E}+01$ & $1.70 \mathrm{E}+02$ & $1.63 \mathrm{E}+02$ & $9.57 \mathrm{E}-01$ \\
\hline $96-06 \mathrm{~L}$ & $6.06 \mathrm{E}+05$ & $9.29 \mathrm{E}+01$ & $9.59 \mathrm{E}+01$ & $1.53 \mathrm{E}+02$ & $1.58 \mathrm{E}+02$ & $1.03 \mathrm{E}+00$ \\
\hline $96-11$ & $1.28 \mathrm{E}+05$ & $4.56 \mathrm{E}+01$ & $4.76 \mathrm{E}+01$ & $3.56 \mathrm{E}+02$ & $3.72 \mathrm{E}+02$ & $1.04 \mathrm{E}+00$ \\
\hline 96-11 L & $7.33 \mathrm{E}+04$ & $1.72 \mathrm{E}+01$ & $1.79 \mathrm{E}+01$ & $2.35 \mathrm{E}+02$ & $2.44 \mathrm{E}+02$ & $1.04 \mathrm{E}+00$ \\
\hline
\end{tabular}


Table 4. K Basin Sludge Analyses for Uranium, ${ }^{239,240} \mathrm{Pu}$, and ${ }^{241} \mathrm{Am}$ (Cont'd)

\begin{tabular}{|c|c|c|c|c|c|c|}
\hline \multirow[b]{2}{*}{ Sample ID } & \multicolumn{6}{|c|}{ Concentration, dry sludge basis } \\
\hline & $\begin{array}{c}\mathrm{U}, \\
\mu \mathrm{g} / \mathrm{g}\end{array}$ & $\begin{array}{c}{ }^{239 / 240} \mathrm{Pu} \\
\mu \mathrm{Ci} / \mathrm{g}\end{array}$ & $\begin{array}{l}{ }^{241} \mathrm{Am}, \\
\mu \mathrm{Ci} / \mathrm{g}\end{array}$ & $\begin{array}{l}{ }^{239 / 240} \mathrm{Pu}, \\
\mu \mathrm{Ci} / \mathrm{g} \mathrm{U}\end{array}$ & $\begin{array}{l}{ }^{241} \mathrm{Am}, \\
\mu \mathrm{Ci} / \mathrm{g} \mathrm{U}\end{array}$ & $\begin{array}{l}\mathrm{Am} / \mathrm{Pu} \\
\mathbf{\mu C i} / \mu \mathrm{hi}\end{array}$ \\
\hline \multicolumn{7}{|c|}{ KW Canister, Makenas et al. 1998} \\
\hline $96-02$ & $2.82 \mathrm{E}+05$ & $5.93 \mathrm{E}+01$ & $4.07 \mathrm{E}+01$ & $2.10 \mathrm{E}+02$ & $1.44 \mathrm{E}+02$ & $6.86 \mathrm{E}-01$ \\
\hline $96-03$ & $94 \mathrm{E}+05$ & $1.49 \mathrm{E}+02$ & $1.44 \mathrm{E}+02$ & $2.15 \mathrm{E}+02$ & $2.07 \mathrm{E}+02$ & $56 \mathrm{E}-01$ \\
\hline $96-16$ & $.14 \mathrm{E}+05$ & $2.22 \mathrm{E}+02$ & $2.97 \mathrm{E}+02$ & $73 \mathrm{E}+02$ & $3.65 \mathrm{E}+02$ & $1.34 \mathrm{E}+00$ \\
\hline 96-17 & $9.20 \mathrm{E}+05$ & $1.97 \mathrm{E}+02$ & $1.86 \mathrm{E}+02$ & $2.14 \mathrm{E}+02$ & $2.02 \mathrm{E}+02$ & 9.44E-01 \\
\hline $96-25$ & $7.38 \mathrm{E}+05$ & $1.69 \mathrm{E}+02$ & $1.70 \mathrm{E}+02$ & $2.29 \mathrm{E}+02$ & $2.30 \mathrm{E}+02$ & $1.01 \mathrm{E}+00$ \\
\hline $96-21$ & $7.98 \mathrm{E}+05$ & $1.38 \mathrm{E}+02$ & $9.35 \mathrm{E}+01$ & $1.73 \mathrm{E}+02$ & $1.17 \mathrm{E}+02$ & $6.78 \mathrm{E}-01$ \\
\hline $96-23$ & $4.73 \mathrm{E}+05$ & $1.07 \mathrm{E}+02$ & $9.03 \mathrm{E}+01$ & $2.26 \mathrm{E}+02$ & $1.91 \mathrm{E}+02$ & 8.44E-01 \\
\hline $96-24$ & $5.40 \mathrm{E}+05$ & $1.37 \mathrm{E}+02$ & $1.12 \mathrm{E}+02$ & $2.54 \mathrm{E}+02$ & $2.07 \mathrm{E}+02$ & $8.18 \mathrm{E}-01$ \\
\hline \multicolumn{7}{|c|}{ Subsurface, Makenas et al. 1999} \\
\hline SSL1 & $9.09 \mathrm{E}+05$ & $1.98 \mathrm{E}+02$ & $1.67 \mathrm{E}+02$ & $2.18 \mathrm{E}+02$ & $1.84 \mathrm{E}+02$ & $8.43 \mathrm{E}-01$ \\
\hline SSl & $8.59 \mathrm{E}+05$ & $1.72 \mathrm{E}+02$ & $1.45 \mathrm{E}+02$ & $2.00 \mathrm{E}+02$ & $1.69 \mathrm{E}+02$ & $8.43 \mathrm{E}-01$ \\
\hline $\mathrm{SS}$ & $9.41 \mathrm{E}+05$ & $2.51 \mathrm{E}+02$ & $2.32 \mathrm{E}+02$ & $2.67 \mathrm{E}+02$ & $2.47 \mathrm{E}+02$ & 9.24E-01 \\
\hline SSL8 & $9.31 \mathrm{E}+05$ & $1.86 \mathrm{E}+02$ & $1.33 \mathrm{E}+02$ & $2.00 \mathrm{E}+02$ & $1.43 \mathrm{E}+02$ & $7.15 \mathrm{E}-01$ \\
\hline \multicolumn{7}{|c|}{ Clad Coatings, Makenas et al. 1999} \\
\hline CS1 & $6.11 \mathrm{E}+05$ & $9.80 \mathrm{E}+01$ & $9.34 \mathrm{E}+01$ & $1.60 \mathrm{E}+02$ & $1.53 \mathrm{E}+02$ & $9.53 \mathrm{E}-01$ \\
\hline $\mathrm{Cs}$ & $1.59 \mathrm{E}+04$ & $4.91 \mathrm{E}+00$ & $7.70 \mathrm{E}+00$ & $3.09 \mathrm{E}+02$ & $4.84 \mathrm{E}+02$ & $1.57 \mathrm{E}+00$ \\
\hline $\mathrm{Cs}$ & $2.20 \mathrm{E}+04$ & $5.20 \mathrm{E}+00$ & $7.31 \mathrm{E}+00$ & $2.36 \mathrm{E}+02$ & $3.32 \mathrm{E}+02$ & $1.41 \mathrm{E}+00$ \\
\hline $\mathrm{C}$ & $2.02 \mathrm{E}+03$ & 4.34E-01 & E-01 & 2.15 & $2.51 \mathrm{E}+02$ & $1.17 \mathrm{E}+00$ \\
\hline CS7 & $7.66 \mathrm{E}+04$ & $1.54 \mathrm{E}+01$ & $1.34 \mathrm{E}+01$ & $2.01 \mathrm{E}+02$ & $1.75 \mathrm{E}+02$ & $8.70 \mathrm{E}-01$ \\
\hline \multicolumn{7}{|c|}{ FE Single-Pull Floor and Pit from KE, Baker and Welsh $2001^{(a)}$} \\
\hline $\mathrm{FE}$ & $1.86 \mathrm{E}+04$ & $2.88 \mathrm{E}+00$ & $2.54 \mathrm{E}+00$ & $1.55 \mathrm{E}+02$ & $1.37 \mathrm{E}+02$ & $8.82 \mathrm{E}-01$ \\
\hline $\mathrm{FH}$ & $1.68 \mathrm{E}+04$ & $5.96 \mathrm{E}+00$ & $4.72 \mathrm{E}+00$ & 3.55 & $.81 \mathrm{E}+02$ & E-01 \\
\hline $\mathrm{FE}$ & $1.21 \mathrm{E}+04$ & $1.32 \mathrm{E}+00$ & $9.52 \mathrm{E}-01$ & 1.09 & $7.87 \mathrm{E}+01$ & $7.21 \mathrm{E}-01$ \\
\hline $\mathrm{FH}$ & $4.10 \mathrm{E}+04$ & $1.31 \mathrm{E}+01$ & $E+01$ & 3.20 & $.54 \mathrm{E}+02$ & 7.94E-01 \\
\hline $\mathrm{FI}$ & $\mathrm{E}+04$ & $1.39 \mathrm{E}+01$ & $\overline{E+01}$ & 3.42 & $2.81 \mathrm{E}+02$ & $8.20 \mathrm{E}-01$ \\
\hline FE-7 & $6.22 \mathrm{E}+04$ & $8.23 \mathrm{E}+00$ & $5.33 \mathrm{E}+00$ & $1.32 \mathrm{E}+02$ & $8.57 \mathrm{E}+01$ & $6.48 \mathrm{E}-01$ \\
\hline \multicolumn{7}{|c|}{ KC Floor and Canister Composite from KE, Baker and Welsh $2001^{(a)}$} \\
\hline $\mathrm{KC}$ & $6.86 \mathrm{E}+05$ & $1.42 \mathrm{E}+02$ & $1.22 \mathrm{E}+02$ & $2.07 \mathrm{E}+02$ & $1.78 \mathrm{E}+02$ & $8.59 \mathrm{E}-01$ \\
\hline KC- & $5.90 \mathrm{E}+05$ & $1.14 \mathrm{E}+02$ & $9.05 \mathrm{E}+01$ & $1.93 \mathrm{E}+02$ & $1.53 \mathrm{E}+02$ & 7.94E-01 \\
\hline $\mathrm{K}$ & $1.66 \mathrm{E}+05$ & $3.92 \mathrm{E}+01$ & $2.92 \mathrm{E}+01$ & 2.36 & $1.76 \mathrm{E}+02$ & $7.45 \mathrm{E}-01$ \\
\hline$\overline{\mathrm{K}}$ & $\mathrm{E}+04$ & $1.31 \mathrm{E}+01$ & +01 & 2.06 & $2.06 \mathrm{E}+02$ & $1.00 \mathrm{E}+00$ \\
\hline KC Can Comp & $6.95 \mathrm{E}+05$ & $1.65 \mathrm{E}+02$ & $1.31 \mathrm{E}+02$ & $2.37 \mathrm{E}+02$ & $1.88 \mathrm{E}+02$ & 7.94E-01 \\
\hline \multicolumn{7}{|c|}{ KE North Load Out Pit Composite, Shelor et al. 2004} \\
\hline Comp & $2.51 \mathrm{E}+04$ & $9.00 \mathrm{E}+00$ & $7.82 \mathrm{E}+00$ & $3.59 \mathrm{E}+02$ & $3.12 \mathrm{E}+02$ & $8.69 \mathrm{E}-01$ \\
\hline DS2, decant & $1.68 \mathrm{E}+05$ & $6.84 \mathrm{E}+01$ & $5.16 \mathrm{E}+01$ & $4.07 \mathrm{E}+02$ & $3.07 \mathrm{E}+02$ & $7.54 \mathrm{E}-01$ \\
\hline $\mathrm{AB} 2, \mathrm{t}$ & $1.22 \mathrm{E}+05$ & $4.73 \mathrm{E}+01$ & $3.56 \mathrm{E}+01$ & $3.88 \mathrm{E}+02$ & $2.92 \mathrm{E}+02$ & $7.53 \mathrm{E}-01$ \\
\hline DE2, middle & $6.84 \mathrm{E}+04$ & $1.80 \mathrm{E}+01$ & $1.67 \mathrm{E}+01$ & $2.63 \mathrm{E}+02$ & $2.44 \mathrm{E}+02$ & $9.28 \mathrm{E}-01$ \\
\hline GH2, bottom & $8.75 \mathrm{E}+03$ & $3.65 \mathrm{E}+00$ & $3.57 \mathrm{E}+00$ & $4.17 \mathrm{E}+02$ & $4.08 \mathrm{E}+02$ & $9.78 \mathrm{E}-01$ \\
\hline \multirow{2}{*}{\multicolumn{4}{|c|}{$\begin{aligned} \text { Average } \\
\text { Standard Deviation }\end{aligned}$}} & $2.55 \mathrm{E}+02$ & $2.35 \mathrm{E}+02$ & $8.91 \mathrm{E}-01$ \\
\hline & & & & $9.63 \mathrm{E}+01$ & $1.11 \mathrm{E}+02$ & $2.38 \mathrm{E}-01$ \\
\hline \multicolumn{4}{|c|}{ Relative Standard Deviation, \% } & 38 & 47 & 27 \\
\hline \multicolumn{7}{|c|}{$\begin{array}{l}\text { (a) Letter report, "Summary of Initial Laboratory Data from the Consolidated and Single Pull Core Sludge } \\
\text { Sampling Campaigns," to K. L. Pearce, 01-SNF/RBB-004, Spent Nuclear Fuel Project, Fluor Hanford, } \\
\text { Richland, WA (May 10, 2001). }\end{array}$} \\
\hline
\end{tabular}


The variabilities of the uranium-specific concentration for plutonium and americium data (respectively, $\pm 38 \%$ and $\pm 47 \%$ ) reflect both the variabilities of individual actinide concentration analyses and the variability in the exposures (burnups) of the individual fuel elements that produced the sludge. The burn-up of discrete fuel elements within the Basins is known to vary from 0 to $6000 \mathrm{MWd}$ per MTU (pages 18 and 22 of Packer 1999). The variability in the ratio of the ${ }^{241} \mathrm{Am}$ to ${ }^{239,240} \mathrm{Pu}$ concentrations, $0.891 \pm 0.238$ or $27 \%$ relative, does not have any contribution by fuel exposure and accordingly is lower. The observed variabilities in the concentration ratios, taken in light of the sample-to-sample exposure variability, are consistent with the $\pm 20 \%$ error typically reported for actinide concentration analyses.

Plots of the uranium-specific concentrations in Figures 1 and 2 show, respectively, the relatively constant uranium-specific concentrations of ${ }^{239,240} \mathrm{Pu}$ and ${ }^{241} \mathrm{Am}$. The concentrations of ${ }^{241} \mathrm{Am}$ with respect to those of ${ }^{239,240} \mathrm{Pu}$ are plotted in Figure 3.

The comparative data in Figures 1 and 2 demonstrate that plutonium and americium concentrations are proportional to those of uranium over a broad range of sludge compositions, even as the uranium concentrations in the sludge vary over a factor of $\sim 460$. This correspondence provides evidence that the plutonium and americium have high affinity for the uranium matrices irrespective of their phase (e.g., uranium metal, $\mathrm{UO}_{2}$, or the more oxidized uranium species). The affinities of plutonium and americium for uranium are even more striking when it is observed that the concentrations of the other sludge solids which might attract and absorb the plutonium and americium (e.g., iron and aluminum oxides and hydroxides, soil minerals, and ion exchange media), increase correspondingly as the uranium concentrations decrease. Even though the non-uranium concentrations increase and uranium concentrations decrease steeply across the sludge materials, the plutonium and americium remain partitioned with the uranium. The distinct association of americium with plutonium shown in Figure 3 gives further evidence of the affinities of the actinides for each other.

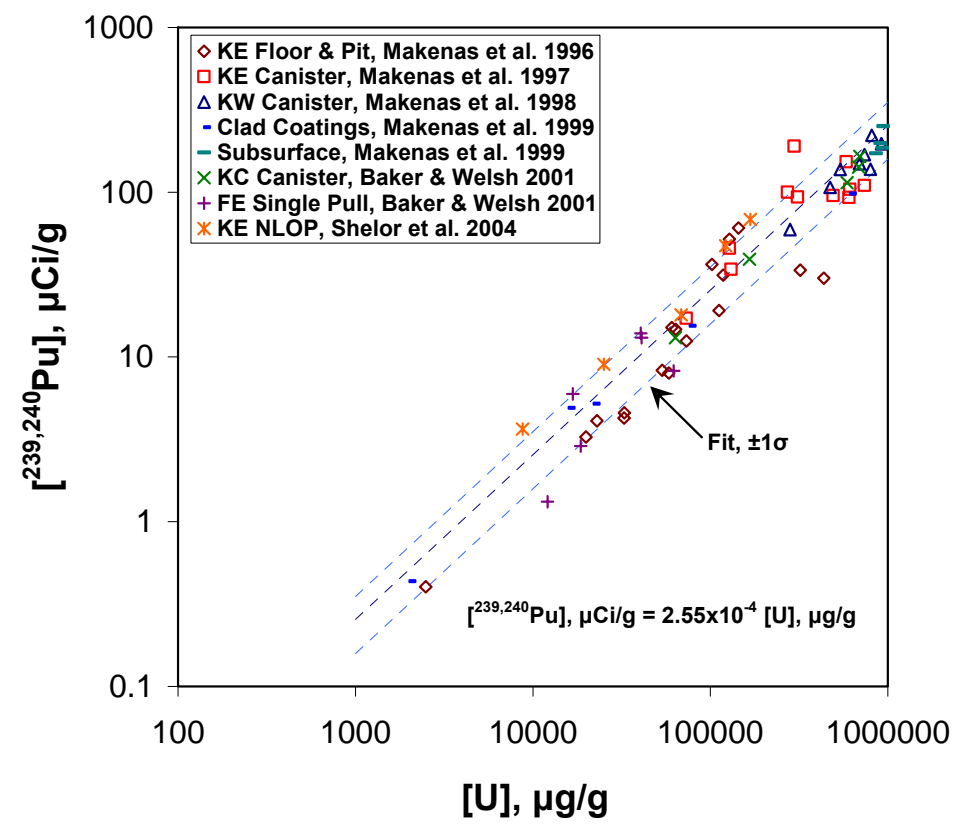

Figure 1. ${ }^{239,240} \mathrm{Pu}$ Concentration with Respect to Uranium Concentration in Dry Sludge 


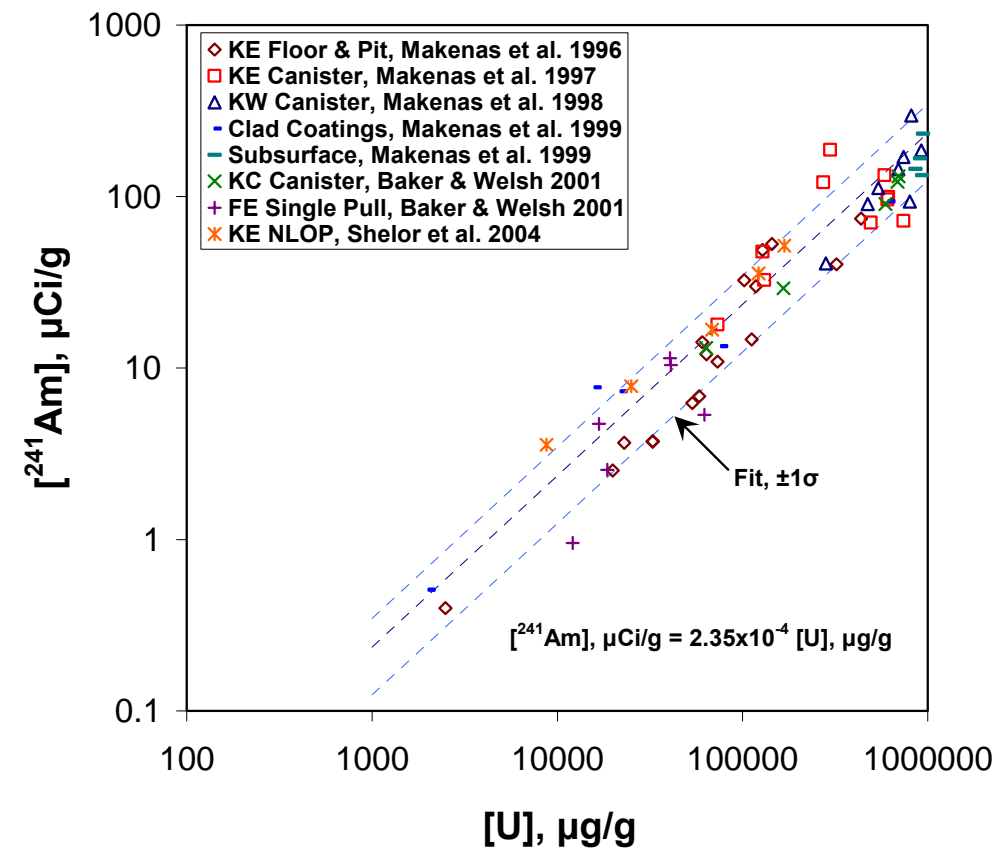

Figure 2. ${ }^{241} \mathrm{Am}$ Concentration with Respect to Uranium Concentration in Dry Sludge

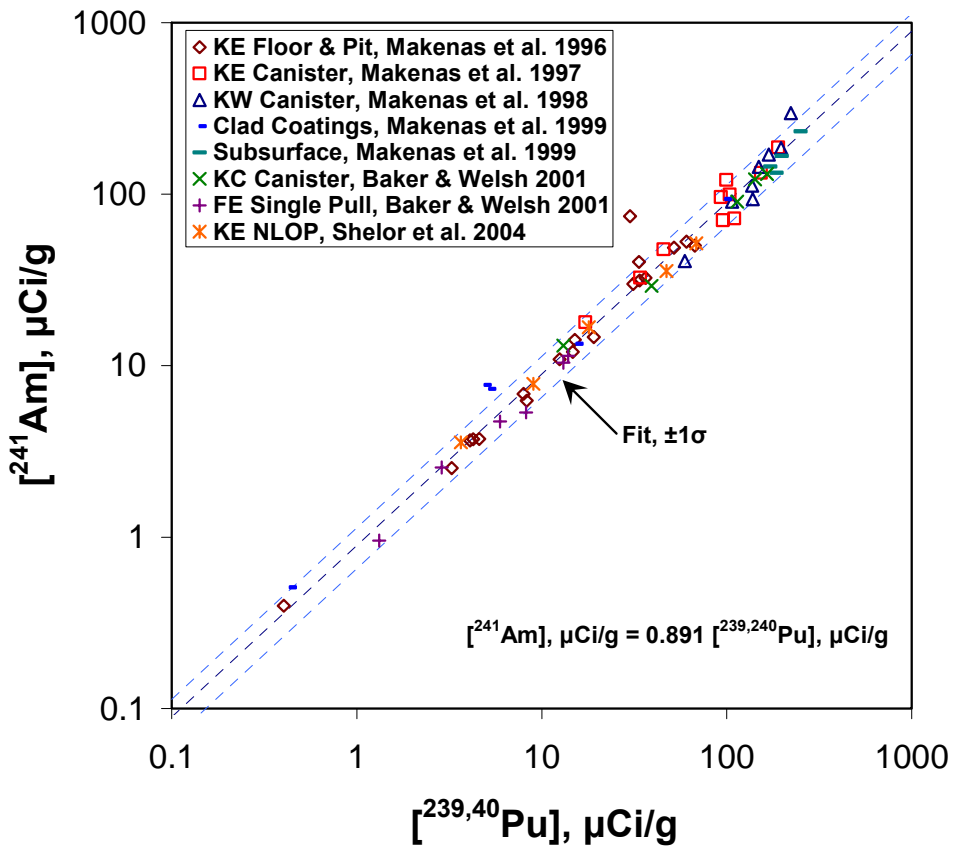

Figure 3. ${ }^{241} \mathrm{Am}$ Concentration with Respect to ${ }^{239,240} \mathrm{Pu}$ Concentration in Dry Sludge 
It is remarkable that the correlation of plutonium and americium with uranium was found even for coatings deposited on exterior (water-side) intact fuel cladding surfaces. Analyses of five coatings scraped from fuel cladding were performed (CS1, CS2, CS3, CS4, and CS7; see Table 4). The uranium concentrations in these coatings ranged widely from $0.2,1.6,2.2$, and 7.7 to $61.1 \mathrm{wt} \%$. Three of the coatings were gray in color, one was red, and one (CS4) was translucent (31 wt\% aluminum). XRD analysis showed that the translucent coating was $\mathrm{Al}(\mathrm{OH})_{3}$ and thus had to be nearly pure $\mathrm{Al}(\mathrm{OH})_{3}$ (itself $\sim 35 \mathrm{wt} \%$ aluminum). It had the lowest observed uranium concentration, $0.2 \mathrm{wt} \%$, of the five coatings. The three iron-rich ( $40-48 \mathrm{wt} \% \mathrm{Fe})$ coatings contained from 1.6 to $7.7 \mathrm{wt} \%$ uranium. Despite the wide range of uranium concentrations and the fact that the aluminum and likely the iron coatings were deposited on the cladding surface directly from solution (though some of the U/Pu/Am could have been deposited as solid particulate suspensions), the uranium-specific plutonium and americium concentrations in the coatings are consistent with, and span, the concentrations found in the other sludge samples.

\subsection{Plutonium and Americium Association with Uranium at Higher Temperatures}

The STP process will place water-laden sludges from the K Basin in autoclaves at $\sim 150-185^{\circ} \mathrm{C}$ with sufficient overpressure to ensure that the water remains in the liquid phase. Therefore, it is of interest to determine whether the strong affinities of plutonium and americium observed for uranium sludge phases created by corrosion at $10-15^{\circ} \mathrm{C}$ will continue under the envisioned hydrothermal conditions. The technical literature were surveyed to find studies of the distributions of the uranium, plutonium, and americium from irradiated fuels to solid and solution phases under hydrothermal corrosion. Such studies might be found in tests associated with fuel storage in saturated fuel repository environments.

Within the United States, studies of fuel corrosion under the spent fuel repository conditions at Yucca Mountain might be relevant. However, the Yucca Mountain repository is designed to operate at atmospheric pressures in which radiolytic heating above $100^{\circ} \mathrm{C}$ would drive liquid water away from the fuel surfaces. Studies of fuel reactions with water for the Yucca Mountain repository therefore are limited to $<100^{\circ} \mathrm{C}$.

Survey of the technical literature did find studies of the behaviors of irradiated CANDU (CANada Deuterium Uranium) fuel under hydrothermal conditions at $95-150^{\circ} \mathrm{C}$ (Stroes-Gascoyne 1992). CANDU fuel is composed of uranium dioxide fuel pellets clad in zircaloy to form fuel rods; the rods are assembled in concentric rings to form cylindrical fuel bundles. The fuel in the tests of interest were of the 37-rod design and arranged in four rings with one rod in the center, 6 inner rods around the center one, 12 intermediate rods around the 6 , and 18 outer rods. CANDU fuel bundles, including the 37-rod design, are shown in Figure 4. 


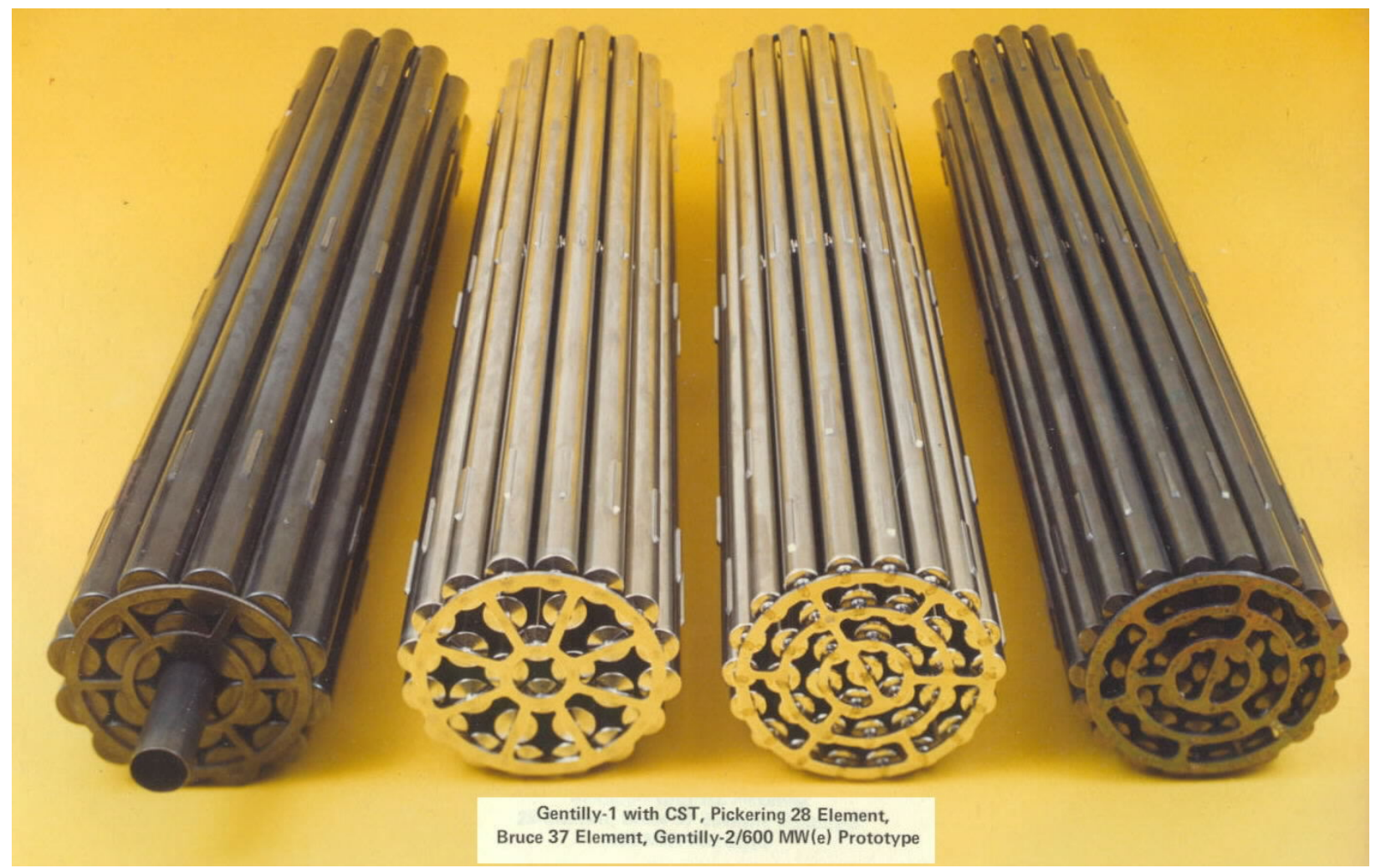

Figure 4. CANDU Fuel Bundles [from http://canteach.candu.org/imagelib/37000-fuelfig120_Bruce booster_Pickering_28 Bruce \&600_MWe_ 37 els.jpg; fuel tested by Stroes-Gascoyne (1992) was taken from Bruce 37 Elements]

Of the 45 liquid water corrosion tests reported by Stroes-Gascoyne (1992), 37 of the tests, and all of the tests of interest to the present study, were conducted with 20 -mm long (13.08-mm diameter) cut clad fuel rod sections. Seven different leach water compositions were used but 26 of the 45 tests, and all tests of interest to the present study, used distilled deionized water. Ten of the 45 tests were conducted at $150^{\circ} \mathrm{C}$, three at $95^{\circ} \mathrm{C}$, and 32 at $100^{\circ} \mathrm{C}$. Of the ten $150^{\circ} \mathrm{C}$ tests, four were conducted in liquid water under mildly reducing conditions (argon cover gas containing 3\% $\mathrm{H}_{2}$ ) but only two of these four tests reported uranium leach amounts and uranium, plutonium, and americium leach concentration data, allowing determinations of their mutual affinities. These two tests thus are at conditions closest to the $150-185^{\circ} \mathrm{C}_{,} \mathrm{H}_{2}$-saturated, and nearly pure water conditions proposed for the STP process. Results from other tests, reporting uranium, plutonium, and americium leaching but run under $\mathrm{Ar} / 3 \% \mathrm{H}_{2}$ at $100^{\circ} \mathrm{C}$ and under air cover gas at 100 and $150^{\circ} \mathrm{C}$ are provided for comparison. All of the tests used rods from the inner (6-rod) ring and all but one of the tests used fuel from the same rod. The test durations were 10 to 34 days and used fuel originating from the Bruce Generating Station.

The experimental conditions and results for the five selected hydrothermal experiments are shown in Table 5. The account by Stroes-Gascoyne (1992) did not provide the fuel burnup (which was given earlier by Stroes-Gascoyne and colleagues in 1987) or the starting concentrations of plutonium and americium in the irradiated fuel. However, the ${ }^{239,240} \mathrm{Pu}$ and ${ }^{241} \mathrm{Am}$ concentrations in CANDU fuel irradiated to $9208 \mathrm{MWD} / \mathrm{MTU}$ are known in other studies (Tait et al. 1995). The ${ }^{239,240} \mathrm{Pu}$ and ${ }^{241} \mathrm{Am}$ concentrations in the fuel tested by Stroes-Gascoyne (1992), irradiated to 10880 or $5440 \mathrm{MWD} / \mathrm{MTU}$, were calculated based on the concentrations found in the $9208 \mathrm{MWD} / \mathrm{MTU}$ irradiated fuel (Tait et al. 
1995) and extrapolations to other exposures made based on curves generated for the ORIGEN reactor (Bell 1973). Those derived concentrations are shown as well in Table 5.

Table 5. Fuel Qualities and Observations in Leach Testing (from Stroes-Gascoyne 1992)

\begin{tabular}{|c|c|c|c|c|c|}
\hline \multirow{2}{*}{$\begin{array}{lr} & \text { Property } \\
\text { Test ID } & \\
\end{array}$} & \multicolumn{5}{|c|}{ Value } \\
\hline & JMDA & JMDB & JMDC & HMDC & HMDA \\
\hline Fuel bundle & BF21271C & BF21271C & BG00815W & BF27271C & BF21271C \\
\hline Element (rod \#) & Interior - 19 & Interior - 19 & Interior - 19 & Interior - 19 & Interior - 19 \\
\hline Average linear power $(\mathrm{kW} / \mathrm{m})$ & 39 & 39 & 33 & 39 & $33^{(a)}$ \\
\hline Burnup, MWD/MTU ${ }^{(\mathrm{b})}$ & 10880 & 10880 & 5440 & 10880 & 10880 \\
\hline $\mathrm{g} \mathrm{Pu} / \mathrm{kg} \mathrm{U}$ in fuel ${ }^{(\mathrm{c})}$ & 4.66 & 4.66 & 2.76 & 4.66 & 4.66 \\
\hline $\mathrm{g} \mathrm{Am} / \mathrm{kg} \mathrm{U}$ in fuel ${ }^{(\mathrm{c})}$ & 0.257 & 0.257 & 0.0232 & 0.257 & 0.257 \\
\hline Xe gas release, $\%$ & 0.13 & 0.13 & 0.065 & 0.13 & 0.13 \\
\hline Redox conditions in leaching & $\begin{array}{c}\mathrm{Ar} / 3 \% \mathrm{H}_{2} \\
\text { anoxic }\end{array}$ & $\begin{array}{l}\mathrm{Ar} / 3 \% \mathrm{H}_{2} \\
\text { anoxic }\end{array}$ & $\begin{array}{l}\mathrm{Ar} / 3 \% \mathrm{H}_{2} \\
\text { anoxic }\end{array}$ & $\begin{array}{l}\text { Air, } \\
\text { oxic }\end{array}$ & $\begin{array}{l}\text { Air, } \\
\text { oxic }\end{array}$ \\
\hline Leaching temper & 150 & 150 & 100 & 150 & 100 \\
\hline Leach time, days & 24 & 25 & 34 & 17 & 10 \\
\hline Leachate $\left[{ }^{238} \mathrm{U}\right], \mathrm{mol} / \mathrm{kg}$ & $3.98 \times 10^{-7}$ & $2.24 \times 10^{-7}$ & $1.12 \times 10^{-6}$ & $1.51 \times 10^{-5}$ & $3.72 \times 10^{-4}$ \\
\hline Leachate $\left[{ }^{239,240} \mathrm{Pu}\right], \mathrm{mol} / \mathrm{kg}$ & $9.77 \times 10^{-10}$ & $8.13 \times 10^{-10}$ & $1.29 \times 10^{-9}$ & $1.07 \times 10^{-9}$ & $7.24 \times 10^{-8}$ \\
\hline Leachate [ $\left.{ }^{241} \mathrm{Am}\right], \mathrm{mol} / \mathrm{kg}$ & $1.12 \times 10^{-11}$ & $1.26 \times 10^{-11}$ & $1.41 \times 10^{-11}$ & $1.02 \times 10^{-11}$ & $2.29 \times 10^{-8}$ \\
\hline Total ${ }^{238} \mathrm{U}$ release, $\%$ & $1.20 \times 10^{-4}$ & $1.50 \times 10^{-4}$ & $3.37 \times 10^{-4}$ & $5.09 \times 10^{-3}$ & $1.11 \times 10^{-1}$ \\
\hline Calc'd. total ${ }^{239,240} \mathrm{Pu}$ release, $\%$ & $6.36 \times 10^{-5}$ & $1.18 \times 10^{-4}$ & $1.41 \times 10^{-4}$ & $7.78 \times 10^{-5}$ & $4.67 \times 10^{-3}$ \\
\hline Calc'd. total ${ }^{241} \mathrm{Am}$ release, $\%$ & $1.33 \times 10^{-5}$ & $3.33 \times 10^{-5}$ & $1.85 \times 10^{-4}$ & $1.36 \times 10^{-5}$ & $2.70 \times 10^{-2}$ \\
\hline \multicolumn{6}{|c|}{$\begin{array}{l}\text { (a) As given by Stroes-Gascoyne (1992) but probably should be } 39 \text { as reported for other samples taken from rod } \\
\# 19 \text { of bundle BF21271C. } \\
\text { (b) Burnup from Stroes-Gascoyne et al. (1987), Table I. } \\
\text { (c) Calculated from actinide concentrations of } 4.15 \mathrm{~g} \mathrm{Pu} / \mathrm{kg} \mathrm{U} \text { and } 0.147 \mathrm{~g}{ }^{241} \mathrm{Am} / \mathrm{kg} \mathrm{U} \text { in CANDU fuel irradiated } \\
\text { to } 9208 \mathrm{MWD} / \mathrm{MTU} \text { and cooled } 15.3 \text { years (Tait et al. 1995) and extrapolations to other exposures as derived } \\
\text { from ORIGEN reactor behavior (Table A-4 in Bell 1973). }\end{array}$} \\
\hline
\end{tabular}

Stroes-Gascoyne (1992) reported the percentage of ${ }^{238} \mathrm{U}$ (effectively, the total uranium) leached from the irradiated fuel in each test and also reported the ${ }^{238} \mathrm{U},{ }^{239,240} \mathrm{Pu}$, and ${ }^{241} \mathrm{Am}$ concentrations in the leachates. The percentage of ${ }^{239,240} \mathrm{Pu}$ and ${ }^{241} \mathrm{Am}$ leached from the irradiated fuel then was calculated based on the reported ${ }^{238} \mathrm{U}$ and calculated ${ }^{239,240} \mathrm{Pu}$ and ${ }^{241} \mathrm{Am}$ starting concentrations in the fuel. These calculated leach percentages also are shown in Table 5 and are presented graphically in Figure 5. 


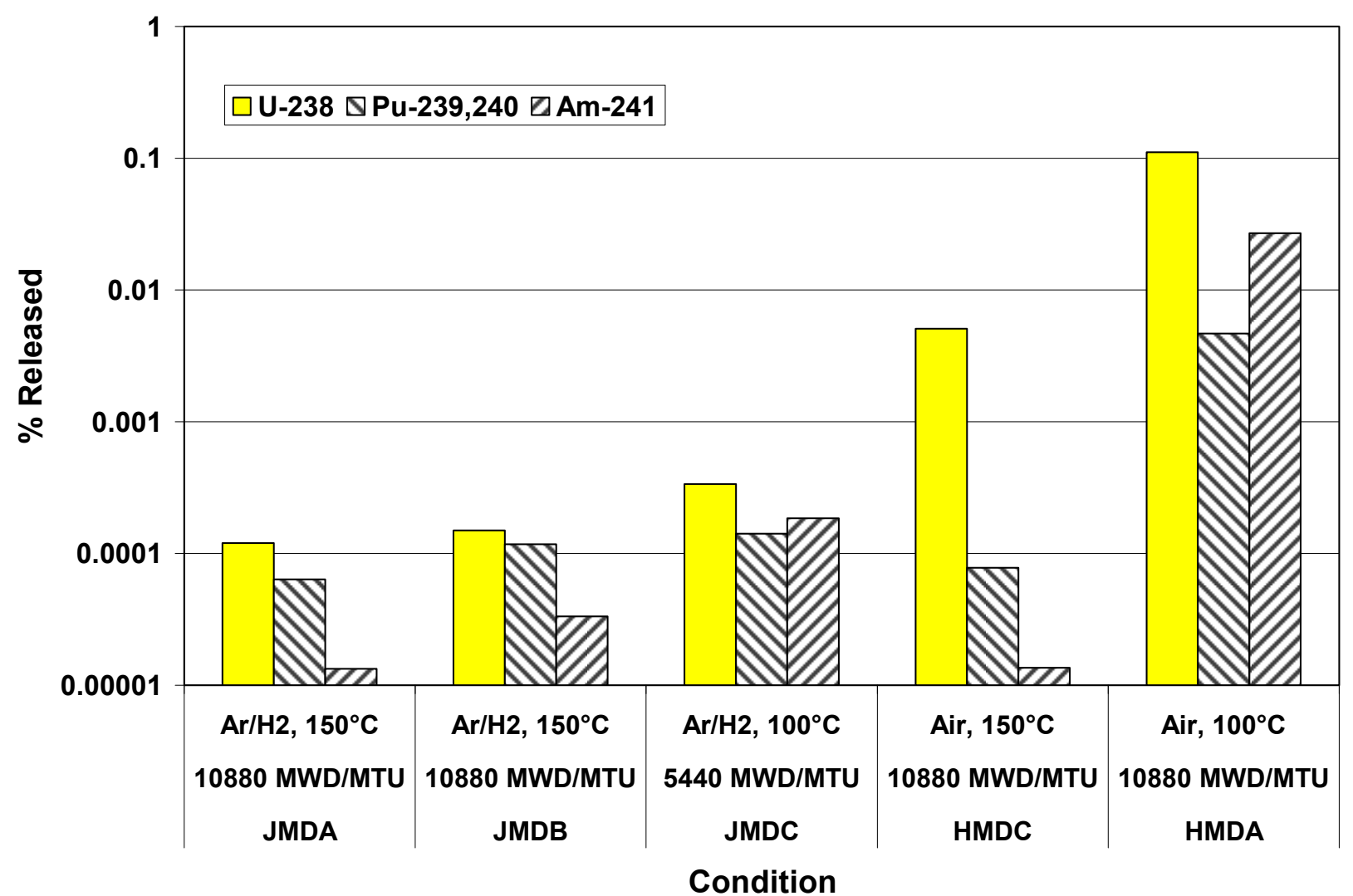

Figure 5. ${ }^{238} \mathrm{U},{ }^{239,240} \mathrm{Pu}$, and ${ }^{241} \mathrm{Am}$ Leached from Irradiated CANDU Fuel under Various Hydrothermal Conditions

The data in Table 5 and Figure 5 show that actinide leaching is lower at $150^{\circ} \mathrm{C}$ than at $100^{\circ} \mathrm{C}$ and generally is lower under the anoxic $\left(\mathrm{Ar} / 3 \% \mathrm{H}_{2}\right)$ conditions than under the oxic (air) conditions. The oxic conditions evidently cause some oxidative dissolution or decomposition of the uranium in the fuel, forming U(VI) solution species and compounds. Significantly, however, the percentages of plutonium and americium leached from the fuel, in every case, are of the same magnitude (i.e., leaching is congruent) or, for $150^{\circ} \mathrm{C}$ oxic conditions, markedly lower than those of the uranium substrate and show no selective leaching from the uranium solids. This behavior is observed not only for anoxic tests at $150^{\circ} \mathrm{C}$ but also for anoxic tests at $100^{\circ} \mathrm{C}$ and for oxic tests at 100 and $150^{\circ} \mathrm{C}$. Most importantly, the plutonium and americium partition overwhelmingly to the solid phase under both oxic and anoxic conditions at $100-150^{\circ} \mathrm{C}$ and remain with the uranium which, in all cases, partitions, at $99.9 \%$ or more, to the solid phase. Under the anoxic $\left(\mathrm{Ar} / 3 \% \mathrm{H}_{2}\right) 150^{\circ} \mathrm{C}$ conditions closest to those proposed for the STP process, uranium, plutonium, and americium partition at $\sim 99.9999 \%$ or better to the solid phase. Given the low solution concentrations of uranium, plutonium, and americium under all studied conditions, there is no credible means to segregate americium from its largely unaltered uranium dioxide host matrix.

\subsection{Conclusions}

Plutonium and americium are found to remain with uranium in the solid phase in $\sim 60$ samples taken from various sources in $\mathrm{K}$ Basin sludge. The uranium-specific concentrations of plutonium and americium 
remain approximately the same over a uranium concentration range (in the dry sludge solids) from 0.2 to $94 \mathrm{wt} \%$, a factor of $\sim 460$.

The affinity of plutonium and americium for uranium in irradiated $\mathrm{UO}_{2}$ also is demonstrated at hydrothermal conditions $\left(150^{\circ} \mathrm{C}\right.$ anoxic liquid water) approaching those proposed for the STP process and even for hydrothermal conditions outside of the STP operating envelope (e.g., $150^{\circ} \mathrm{C}$ oxic and $100^{\circ} \mathrm{C}$ oxic and anoxic liquid water).

The results of these two data sets give confidence that plutonium and americium will remain with the solid phase and specifically with uranium during the hydrothermal STP process. Combined with the dispersal of the americium at 1 atom per 19000 of uranium, this would support the use of uranium as the transportability class for the contained americium for spent fuel in the STP process.

\subsection{References}

Amme, M. 2002. "Contrary Effects of the Water Radiolysis Product $\mathrm{H}_{2} \mathrm{O}_{2}$ upon the Dissolution of Nuclear Fuel in Natural Ground Water and Deionized Water," Radiochimica Acta 90:399-406.

Bell, MJ. 1973. ORIGEN - The ORNL Isotope Generation and Depletion Code. ORNL-4628, Oak Ridge National Laboratory, Oak Ridge, TN.

Delegard, CH, SA Bryan, AJ Schmidt, PR Bredt, CM King, RL Sell, LL Burger, and KL Silvers. 2000. Gas Generation from K East Basin Sludges - Series I Testing. PNNL-13320, Pacific Northwest National Laboratory, Richland, WA.

Eidson, AF. 1980. Comparison of Physical Chemical Properties of Powders and Respirable Aerosols of Industrial Mixed Uranium and Plutonium Oxide Fuels. NUREG/CR-1736, U.S. Nuclear Regulatory Commission, Washington, DC.

Ekeroth, E, M Jonsson, TE Eriksen, K Ljungqvist, S Kovács, and I Puigdomènech. 2004. "Reduction of $\mathrm{UO}_{2}{ }^{2+}$ by $\mathrm{H}_{2}$, , Journal of Nuclear Materials 334:35-39.

Ekeroth, E, O Roth, and M Jonsson. 2006. “The Relative Impact of Radiolysis Products in Radiation Induced Oxidative Dissolution of $\mathrm{UO}_{2}$," Journal of Nuclear Materials 355:38-46.

ICRP. 1972. The Metabolism of Compounds of Plutonium and Other Nuclides, International Commission on Radiological Protection, ICRP Publication 19, Pergamon Press, New York, NY.

ICRP. 1979. "Limits for Intakes of Radionuclides by Workers," ICRP Publication 30, part 1, International Commission on Radiological Protection, Annals of the ICRP 2(3-4), Pergamon Press, New York, NY.

ICRP. 1994. "Dose Coefficients for Intakes of Radionuclides by Workers," ICRP Publication 68, International Commission on Radiological Protection, Annals of the ICRP 24(4), Pergamon Press, New York, NY. 
ICRP. 1995a. "Age-Dependent Doses to Members of the Public from Intake of Radionuclides: Part 5 Compilation of Ingestion and Inhalation Dose Coefficients," ICRP Publication 72, International Commission on Radiological Protection, Annals of the ICRP 26(1), Pergamon Press, New York, NY.

ICRP. 1995b. "Age-Dependent Doses to Members of the Public from Intake of Radionuclides: Part 4 Inhalation Dose Coefficients," ICRP Publication 71, International Commission on Radiological Protection, Annals of the ICRP 25(3/4), Pergamon Press, New York, NY.

Katz, JJ, LR Morss, and GT Seaborg. 1986. "Summary and Comparative Aspects of the Actinide Elements," chapter 14 in The Chemistry of the Actinide Elements, $2^{\text {nd }}$ edition, J. J. Katz, G. T. Seaborg, and L. R. Morss, editors, Chapman and Hall, London, UK.

Makenas, BJ, TL Welsh, RB Baker, DR Hansen, and GR Golcar. 1996. Analysis of Sludge from Hanford K East Basin Floor and Weasel Pit. WHC-SP-1182, Westinghouse Hanford Company, Richland, WA.

Makenas, BJ, TL Welsh, RB Baker, EW Hoppe, AJ Schmidt, J Abrefah, JM Tingey, PR Bredt, and GR Golcar. 1997. Analysis of Sludge from Hanford K East Basin Canisters. HNF-SP-1201, Duke Engineering and Services Hanford, Inc., Richland, WA.

Makenas, BJ, TL Welsh, RB Baker, GR Golcar, PR Bredt, AJ Schmidt, and JM Tingey. 1998. Analysis of Sludge from Hanford K West Basin Canisters. HNF-1728, Rev. 0, Fluor Daniel Hanford, Richland, WA.

Makenas, BJ, TL Welsh, PR Bredt, GR Golcar, AJ Schmidt, KL Silvers, JM Tingey, AH Zacher, and RB Baker. 1999. Analysis of Internal Sludge and Cladding Coatings from N-Reactor Fuel Stored in Hanford K Basins. HNF-3589, Fluor Daniel Hanford, Inc., Richland, WA.

Packer, M. 1999. 105-K Basin Material Design Basis Feed Description for Spent Nuclear Fuel Project Facilities, Volume 1, Fuel. HNF-SD-SNF-TI-009, Vol. 1, Rev. 3, Numatec Hanford, Inc., Richland, WA.

Plys, MG and AJ Schmidt. 2006. Supporting Basis for Spent Nuclear Fuel Project Sludge Technical Databook. SNF-7765, Rev. 3C, Fluor Hanford, Richland, WA.

Puigdomènech, I, and J Bruno. 1988. Modelling Uranium Solubilities in Aqueous Solutions: Validation of a Thermodynamic Data Base for the EQ3/6 Geochemical Codes, SKB 88-21, Svensk Kärnbränslehantering $\mathrm{AB}$, Stockholm, Sweden.

Rai, D, AR Felmy, NJ Hess, VL Legore, and DE McCready. 2002. "Thermodynamics of the U(VI)$\mathrm{Ca}^{2+}-\mathrm{Cl}-\mathrm{OH}-\mathrm{H}_{2} \mathrm{O}$ System: Solubility Product of Becquerelite," Radiochimica Acta 90:495-503.

Sandino, MCA, and B Grambow. 1994. "Solubility Equilibria in the U(VI)-Ca-K-Cl- $\mathrm{H}_{2} \mathrm{O}$ System," Radiochimica Acta 66/67:37-43.

Schmidt, AJ. 2006. Spent Nuclear Fuel Project Technical Databook, Vol. 2, Sludge. HNF-SD-SNF-TI015, Rev. 13A, Fluor Hanford, Richland, WA. 
Schmidt, AJ, and CH Delegard. 2003. Updated Volumetric Expansion Factors for K Basin Sludge During Storage, PNNL-14228, Pacific Northwest National Laboratory, Richland, WA.

Schmidt, AJ, CH Delegard, SA Bryan, MR Elmore, RL Sell, KL Silvers, SR Gano, and BM Thornton. 2003. Gas Generation from K East Basin Sludges and Irradiated Metallic Uranium Fuel Particles Series III Testing. PNNL-14346, Pacific Northwest National Laboratory, Richland, WA.

Shelor, JL, M Epstein, MG Plys, JP Sloughter, J Abrefah, CH Delegard, and AJ Schmidt. 2004. Gas Behavior in Large Diameter Containers (LDCs) During and Following Loading with 105K East North Loadout Pit Sludge. SNF-22059, Fluor Hanford, Richland, WA.

Stradling, GN and JW Stather. 1989. "The Use of Animal Experiments for Assessing Annual Limits on Intake and Interpreting Chest-Monitoring Data for Workers Exposed to Industrial Actinide-Bearing Dusts," Health Physics 57: Supplemental 1:221-228.

Stroes-Gascoyne, S. 1992. "Trends in the Short-Term Release of Fission Products and Actinides to Aqueous Solution from Used CANDU Fuels at Elevated Temperatures," Journal of Nuclear Materials 190:87-100.

Stroes-Gascoyne, S, LH Johnson, and DM Sellinger. 1987. "The Relationship between Gap Inventories of Stable Xenon, ${ }^{137} \mathrm{Cs}$, and ${ }^{129} \mathrm{I}$ in Used CANDU Fuel," Nuclear Technology 77:320-330.

Tait, JC, I Gauld, and AH Kerr. 1995. "Validation of the ORIGEN-S Code for Predicting Radionuclide Inventories in Used CANDU Fuel," Journal of Nuclear Materials 223:109-121. 